\title{
Brexit and European Citizenship: Welcome Back to International Law
}

\author{
Ignacio FORCADA BARONA*
}

\begin{abstract}
The emergence of European citizenship in $199^{2}$ was considered an important step forward in the "constitutionalization" of the Community legal order. As it was formulated, European citizenship was little more than a compilation of the rights contained in the founding Treaties and secondary law. But the CJEU, supported by a prointegrationist academic doctrine, turned it into the "fundamental status of the nationals of the Member States". It is not surprising then that many scholars considered Brexit, which involved the loss of European citizenship for millions of UK nationals, a disappointment. Some of them looked at international law trying to find some limits to the most serious effects of Brexit on the rights of European citizens. The aim of this article is precisely to analyse in detail those doctrinal discours es that resort to international law as a possible constraint on state sovereignty. At the end we will see that these proposals are based not only on a methodological misperception of what international law is and what it is for, but also on a serious distortion of the real meaning of European citizenship.
\end{abstract}

Keywords: Brexit - European citizenship - Court of Justice of the European Union - International law.

(A) BREXIT AND...

The terms used by the academic doctrine interested in the process of European integration to describe the British decision to leave the European Union (EU), after 47 years of membership, ' give an idea of its

¿ Article received on ${ }_{3 I}$ July 2020 , accepted on 26 October 2020 and published on ${ }_{3 I}$ December 2020

* Professor of Public International Law and International Relations, Universidad de Castilla-La Mancha at Toledo. Email: Ignacio.forcada@uclm.es.

r The process of the UK's exit from the European Union, universally known as Brexit, started to take shape on 23 June 2016 when British citizens, by a majority of $5{ }^{1.89} \%$ of the votes cast, expressed their decision to withdraw from the EU in a referendum convened by Prime Minister David Cameron. The other key dates of the disengagement process have been 29 March 2017, when the UK formally activated the withdrawal process provided for in Article $5^{\circ}$ of the Treaty on European Union (TEU); r7 October 2019 when the EU adopted the Agreement on the withdrawal of the United Kingdom of Great Britain and Northern Ireland from the European Union and the European Atomic Energy Community (the Agreement); and midnight on 3 I January 2020, the date on which the UK formally leaves the Union, although according to Article 126 of the Agreem ent, it has to continue to apply Union law on a transitional basis until $3^{\mathrm{I}}$ December 2020. For details of the referendum and its result, see The Electoral Commission, Results and turnout at the EU referendum; y S. Bonnecke, "Brexit-iQuo Vadis?", $5^{\mathbf{I}}$ Estudios Internacionales (2019) 9-36 [doi:10.5354/o719-3769.2019.54136]. Obviously, the profound reasons that have led to the withdrawal of the UK go back much further in time and their study, in view of all the political and legislative vicissitudes experienced by the British side in the process of withdrawal, is almost better approached from the political, social and cultural psychology. See K. McEvoy, A. Bryson, \& A. Kramer, "The Empire Strikes Back: Brexit, the Irish Peace Process, and the Limitations of Law", 43 Fordham International Law Journal (2020) 615-668, and its bibliography. Also J. Frosini \& M.F. Gilbert, "The Brexit car crash: using E.H. Carr to explain Britain's choice to leave the European Union in 20I6", 27 Journal of European Public Policy (2020) 76 1-778 [doi:10.ro8o/1350I763.20I9.167682o]; G. A. Veltri et al., "The identity of Brexit:A cultural psychology analysis”, 29 Journal of Community \& Applied Social Psychology (2019) I8-3I [doi: ro.roo2/casp.2378]; A. Golec de Zavala, R. Guerra \& C. Simão, "The Relationship between the Brexit Vote and Individual Predictors of Prejudice: Collective Narcissism, Right Wing Authoritarianism, Social Dominance Orientation”, 8 Frontiers in Psychology (2017) I-I/4 
apparent historical, geopolitical, sociological and legal significance; the drama and concern with which it was received. "Earthquake”, “tremor”, “crisis”, “abyss”, “regression”, “confusion”, "discouragement”, “uncertainty”, “farce”, "risky experiment”, “danger”. ${ }^{2}$ Those most prone to tragedy spoke of a dying EU, if not already being dead and buried. For others the integration project was damaged "beyond repair or redemption". ${ }^{3}$ Some commentators spoke, in one of the most curious revivals of the theory of the "domino effect", which had so much predicament during the Cold War between the US military and politicians, of a spiral of exits from the Union, following in the British wake, which would inevitably lead to the dissolution of the EU.4 Or to its decline, if a new European patriotism did not emerge (sic). ${ }^{5}$

As expected, this emotional impact was translated into an avalanche, in the most literal sense of the word, of academic literature whose objective was to analyse the repercussions of Brexit in the most diverse fields of knowledge. What I call "Brexit and ..." left on the other side of the binomial an infinite variety of terms that ranged from the balance of power in Europe to anti-politics, including international law, the environment or pig farming, among hundreds of possibilities. ${ }^{6}$ From an international legal-political point of view, the "Brexit and European citizenship" binomial is definitively worth studying. ${ }^{7}$

[doi:ı.3389/fpsyg.2017.02023]; and 39 Political Psychology, special number devoted to The Political Psychology of European Integration: Brexit and Beyond.

See S. Ahlhaus \& P. Niesen, "Regression in membership law: For a cosmopolitanism from within", 26 Constellations (2019) 492-503 [doi: 10.III/1467-8675.12433]; A. Mangas, "PostBrexit: una Europa confusa, entre el desánimo y la incertidumbre”, 54 Revista de Derecho Comunitario Europeo (2016) 427-437; J.L. Marco, "El Brexity el futuro de la Unión Europea", $5^{\mathrm{I}}$ Actualidad Jurídica Uría Menéndez (2019) 7-18; J.L. Malo, "El futuro del proyecto europeo después del Brexit", 896 Información Comercial Española, ICE, Revista de economáa (2017) I/4I-I52; C. Di Maio \& A. Tomás, "La ciudadanía europea ante el reto de la unidad política: đmero estatuto de libertades o motor para una sólida integración de la Unión Europea?", qo Revista Derecho del Estado (2018) I8I-208 [Doi: I0.I86or/or229893.n40.o8]; V. Power, "Brexit: Legal and Policy Lessons learned for the European Union, the Withdrawal Process and European Union Law", 2I Irish Journal of European Law (2018) 36-54; O. Garner, "After Brexit: Protecting European citizens and citizenship from fragmentation”, EUI Working Papers, LAW $2016 / 22$ I2 [ [doi: 10.2139/ssrn.2871404]; J. Klabbers, "Continent in Crisis”, 27 EuropeanJournal of International Law (2016) $553-556$ [doi.org/ı.ı.1093/ejil/chwo29].

3 For a sample of the most pessimistic analyses, see R. Maher, "International Relations Theory and the Future of European Integration", o International Studies Review. Analytical Essays (2020) I-26, at I-2 [doi: 10.1093/isr/viaaoıo/ 5775616$]$.

4 H. Yergiin, "Does Brexit Would Cause Domino Effect on Other European Union Countries? Is It the End of Regional Integrations?”, 6 International Journal of Humanities and Social Science Invention (2017) 3I-43.

5 G. Schwan et al., "Guest Editorial: Without a newEuropean patriotism, the decline of the EU is inevitable", EJIL:Talk, April 2020.

${ }^{6}$ An example of the infinite possibilities of this "Brexit and...", can be seen in P. Diamond, P. Nedergaard \& B. Rosamond (eds), The Routledge Handbook of the Politics of Brexit (Routledge, London, 2018), at v-vii.

7 The consultation of the term "Brexit and international law" in the Oxford Public International Law (OPIL) returns a reading list of four sections: history/background, treaties, trade agreements, borders/secession/sovereignty, and citizenship. The doctrine most concerned with formal legal aspects has mainly dealt with the effects of Brexit on the treaties concluded by the EU. See J. Odermatt, "Brexit and International Law: Disentangling Legal Orders", 3I Emory International Law Review (2017) 1052-1073; G. Van der Loo \& S. Blockmans, "The Impact of Brexit on the EU's International Agreements", Centre for European Policy Studies,Policy Paper (2016); Ch. Hillion, "Consequences of Brexit for international agreements concluded by the EU and its Member States”, 55 Common Market Law Review (2018) roI-I31. The Spanish doctrine has focused on 
In fact, as early as Van Gend \& Loos, the Court of Justice of the European Union (CJEU) had made it clear that the Community legal order was somewhat different from the traditional international legal order, ${ }^{8}$ which led many to believe that we were facing a reality radically different from the imperfect world of international law in which individuals have a very limited role. With the passage of time, and the invaluable help of the CJEU, which already in its Opinion I/9I declared that the Treaty establishing the EEC was the "the constitutional charter of a Community based on the rule of law", ${ }^{9}$ the most proEuropean academic doctrine allowed itself to affirm that the Court had de facto constitutionalized the Community legal order, making it more supranational and less intergovernmental. ${ }^{10}$

The emergence of European citizenship in $199^{2}$ put the finishing touches to this supposed “constitutionalization” of the Community legal order. After all, what better proof of supranationality than the possibility, implicit in the new European citizenship, of political membership and individual and collective self-determination beyond the borders of the nation state? And taken to the extreme, did not European citizenship imply a questioning of nationality as a matter reserved for strict state competence - a de facto relativization, if not abolition, of Member States' nationality since the rights it granted were totally dissociated from the nationality that had given access to the status?

It is not surprising that Brexit fell like cold water on such a markedly Europeanist academic community, provoking the sudden awakening of all those who were beginning to describe reality in post-national terms. European citizenship has a derivative character - only those who have the nationality of a Member State are European citizens - and consequently, it is apparently lost with the departure of a state from the EU. What kind of constitutional order are we talking about, then, when a Member State can, from one day to the next, deprive more than sixty million people of a significant part of their, to use the very words of the CJEU in Van Gend \& Loos, "legal heritage". Was not the role of individuals, their legal subjectivity, the great difference between international and Community law? How can the rights of millions of European citizens be left at the mercy of the mere will of the state, however democratically formed it may be? Does this not resemble too much the normal functioning of international law?

Suddenly, international law seemed to reappear through the back door in the Community legal order. Welcome back to International law. Something that James Crawford put in even more ironic

the consequences of Brexit on the Gibraltarian dispute. See M. Martín \& J. Martín (coord.), El Brexit y Gibraltar. Un reto con oportunidades conjuntas (Ministerio de Asuntos Exteriores y Cooperación, Madrid, 20I7); A. Del Valle, “Gibraltar, the Brexit, the Symbolic Sovereignty, and the Dispute. A Principality in the Straits?”, Cuadernos de Gibraltar - Gibraltar Reports, No. 2 (2017) 67-96 [doi: I0.25267/Cuad_Gibraltar.2oi7.i2.o5]; A. Mangas, “ ¿Brexit? Escenarios internacionales y Gibraltar”, Real Instituto Elcano Documento de Trabajo g/2or6. You can also find articles on the rights of European citizens: J.J. Piernas, "Derechos de los ciudadanos de la Unión Europea y del Reino Unido después del Brexit”, 35 Anuario Español de Derecho Internacional (2019) 26I-295 [doi: Io.I558I/oro.35]; technical analysis on CJEU rulings: P. Andrés, "Un tribunal a la altura de sus responsabilidades: el Brexit ante el Tribunal de Justicia de la Unión Europea”, 62 Revista de Derecho Comunitario Europeo (2019) I737 [doi.org/ı.ı8o42/cepc/rdce.62.or]; or contributions of a general nature: S. Torrecuadrada \& P. García, “¿Qué es el Brexit? Origen y posibles consecuencias”, XVII Anuario Mexicano de Derecho Internacional (2017) 3-40 [D0I: doi: I0.2220I/iij.24487872e.20I7.I7.IIO3o].

8 Judgment of the Court of 5 February I $_{9} 6_{3}$, -NV Algemene Transport- en Expeditie Onderneming van Gend \& Loos v Netherlands Inland Revenue Administration, Case 26-62, at I2, ECLI:EU:C:I963:I.

9 Opinion of the Court of I 4 December r99ı, Opinion I/9I, ECLI:EU:C:I99ı:49o.

ı See infra paragraph (D). 
words when he said, at the I2th Annual Conference of the European Society of International Law, that international law was "all that remains when 'Brexit' happens or when Donald Trump wins the US

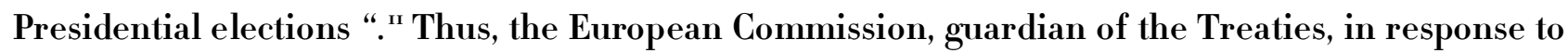
questions about the impact on European citizenship of the opening up of a hypothetical secession of part of a Member State's territory, ${ }^{12}$ answered without hesitation that " in the hypothetical event of a secession of a part of an EU Member State, the solution would have to be found and negotiated within the international legal order " ${ }^{13}$ Similarly, the CJEU used it as support in one of its decisions on Brexit which, curiously enough, for some reaffirmed the constitutional nature of EU law. ${ }^{1 / 4}$ Along the same lines, and also paradoxically, many of those who considered that international law as the guiding principle of European regional relations was dépassé began to turn to it in search of limits that would alleviate the consequences of Brexit on citizens' rights.

The aim of this article is precisely to analyse in detail the doctrinal discourses that resort to international law to find some limits to the most serious effects of Brexit on the rights of European citizens. To this end, after a review of the origins of European citizenship, and the CJEU's interpretation of it, we will look in detail at some of the doctrinal proposals to avoid the loss of citizenship rights as a result of the United Kingdom's exit from the EU. At the end of the journeywe will see that these proposals are based not only on a serious distortion of the real meaning of European citizenship, but also on a methodological misperception of what international law is and what it is for.

\section{(B) THE BIRTH OF A POST-NATIONAL CITIZENSHIP}

Like other administrations, both national and international, the EU is in the habit of giving its citizens, from time to time, slogans or ideas whose objective is to facilitate our understanding of its problems and activities, while serving to orient and focus its energies at a given time and in a given direction. In I98 $8_{5}$, when I was graduating in European law from the Institute of European Studies (IEE) of the Free University of Brussels, the mot d'ordre was the "democratic deficit" and the "Europe of the citizens. ${ }^{15}$

" Quoted in I. De la Rasilla, “International Law in the Early Days of Brexit's Past”, EJIL: Talk (2020).

12 Parliamentary question by Mara Bizzotto (EFD), E-oo7453/2012, 25 July 2012; and Parliamentary question by Izaskun Bilbao Barandica (ALDE), Ramon Tremosa i Balcells (ALDE), Salvador Sedó i Alabart (PPE) and Raül Romeva i Rueda (Verts/ALE), E-oo8I33/2012, I7 September 20 I2.

I3 Answer given by Mr Barroso on behalf of the Commission, P-oog756/12 and P-oog862/ı2, 3 December 2012.

I/4 Judgment of the Court (Full Court) of io December 20I8, Andy Wightman and Others v Secretary of State for Exiting the European Union, Case C-62I/18, ECLI:EU:C:2or8:999. After recalling the autonomy of Union law, "both to the law of the Member States and to international law", the Court, apparently unsure of its own reasoning, ends up confirming it with "the provisions of the Vienna Convention on the Law of Treaties, which was taken into account in the preparatory work for the Treaty establishing a Constitution for Europe”. On the constitutional significance that some attribute to this decision, see Andrés, supra n. 7, at 32; and P. Eeckhou \& E. Frantziou, "Brexit and Article 5o TEU: A constitutionalist reading", 54 Common Market Law Review (2017) 695-734 [doi.org/10.2139/ssrn.2889254].

${ }_{5}$ The expression “democratic deficit” was first used by the English academic and parliamentarian David Marquand, in his 1979 book $A$ Parliament for Europe (Cape, London). See P. Mindus, European Citizenship after Brexit. Freedom of Movement and Rights of Residence (Palgrave Macmillan, London, 20I7), at 9. See the definition of "democratic deficit" in the glossary contained in the Eur-lex database of European legislation. The first initiatives for a "Citizens' Europe" date from the late $1960 \mathrm{~s}$, although the first time the expression appears in a legal source is in the ${ }_{9} 87$ Council Decision on the Erasmus programme. See S. Kadelbach, "Union Citizenship“, 
Without forgetting, of course, the hype caused by the Commission's White Paper on the measures needed to achieve the much-desired internal market once and for all. ${ }^{16}$

Busy, and fascinated, as were my Spanish fellow students and I, learning to navigate, before Spain's accession to the European Communities (EC), by the subtle complexities of its legal order - and also by the immense bureaucracy of acronyms and abbreviations physically embodied in the urban landscape of Brussels-, we could not yet realize that in relation to slogans, mots d'ordre and other resources of the Community communication strategy, the EU is one of the best empirical proofs of the factual existence of the eternal return.

Indeed, the EU's long-standing "democratic deficit”- the lack of direct participation by the citizens of the Member States in its institutions and decision-making procedures, and the complexity of these - was not new in the history of the Community. Already in the late r96os, the EC had considered various initiatives to make the whole Community building more accessible to its inhabitants, to raise their interest in its fate, and to strengthen its democratic character. ${ }^{17}$

But it is in the r97os that the EC seems to take its democratic health seriously. Under the impetus of Valéry Giscard d'Estaing and Helmut Schmidt, interested in relaunching the idea of a genuine political process in Europe based on citizen participation, the European Council proposes two concrete measures: a reflection on the civil and political rights that could be granted to European citizens in order to bring them closer to EC institutions and policies, and the election by universal suffrage of Members of the European Parliament. ${ }^{18}$ Of the two, only the second would take shape, but the slow community machinery had finally started up and all we could do was sit and wait.

And the truth is that this time it was not necessary to wait long. It will be precisely in the 1980 's when the "citizens moment" arrived. The pro-European sectors, in favor of a greater political union between the Member States, with Altiero Spinelli at their head, concluded that the only way to promote greater union was through the involvement of the citizenry. His draft "Treaty to establish a European Union", which included the creation of a true European citizenship, would never see the light of day. ${ }^{19}$ But, in the short term, it would help the European Council held in Fontainebleau in r984 to revive the idea of a citizens' Europe and to create a committee that would propose measures so that the EC could move in that direction. The two reports that were drafted in that committee, which informally received the

Jean Monnet Working Paper 9/o3 (2003) I-56, at. 6-8.

I6 Nor the imminent holding of the intergovernmental conference that would lead to the adoption of the Single European Act and, with it, the extension of the Community's powers in the ever-welcome direction of greater integration of its Member States.

17 See Commission of the EC (1970), Third General Report on the Activities of the Communities Ig69.

i8 Paris Summit of Io December I974. At the European Council in The Hague on 30 November I976, the Heads of State and Government recognized, in the same vein, the need for "the attachment of the peoples" to the construction of the Community. See M. Catala, "From the Europe of citizens to European citizenship, I974-I992", Encyclopédie pour une histoire nouvelle de l'Europe [online], published 14 November 2or8; and E. Deschamps, “L'Europe des citoyens”, Centre Virtuel de la Connaissance sur l'Europe, published 8 July 2or6. Already in the preamble to the final communiqué of the I972 Paris Summit it was stated "the will of the members to base the development of the Community on political democracy, freedom of opinion, the free movement of persons and ideas and the full participation of the people through their duly elected representatives". See an analysis of this Summit in C. Westendorp, “La Cumbre de París”, I Revista de Instituciones Europeas (1974) I65-I72, at I7I.

ig In the medium term, the draft Treaty would also serve as a basis for the Single European Act and the Maastricht Treaty. 
name of its former president, the Italian politician Pietro Adonnino, contained a whole series of proposals whose ultimate objective was, on the one hand, to make citizens enjoy tangible benefits as a consequence of their membership in the EC and, on the other, to reinforce the image of the EC before their citizens and before the world. ${ }^{20}$

We can now leave aside the proposed measures concerning the image of the EC, especially the flag, the anthem and Europe Day, which gave my friends and I such an hilarious moment in that May 1986 when the flag was first raised before our eyes in the courtyard of the EC Commission's headquarters, the iconic Berlaymont building, while the EC choir sang Beethoven's Ode to Joy, its new anthem. ${ }^{21}$ But if one reads carefully the measures that the Adonnino Committee suggested so that ordinary citizens would finally realize that the $\mathrm{EC}$ was not an abstract and distant entity without any impact on their lives, but the great and useful invention that it really was, one will immediately realize that a large part of them were incorporated as such into the new European citizenship that was introduced in our lives in 1992 with the Maastricht Treaty. ${ }^{22}$ With the invaluable help, it must be said, of the fall of the Berlin wall and, allow me some chauvinism, of Spain's accession to the EC, with its irrepressible Europeanism after such a long isolation.

The fall of the Berlin Wall was one of those foundational moments when time seemed to stand still. After the initial fears of the unknown, which the inevitable German reunification seemed to awaken among the European political class, it soon became evident that the guarantee that Germany would never return to its historic ways was to strengthen the union of the EC countries not only economically but also, and much more importantly, politically. And that this deepening of the union between the Member States, which involved hitherto unknown transfers of sovereignty to a supranational entity, could only be done with popular support. The way was cleared for the measures proposed by the Adonnino Committee to become a reality. After all, what popular support could there be for something whose functioning and usefulness were not even known? It was clear, to use the words of the everintelligent Jacques Delors, that no one was going to fall in love with a common market. Something else was needed. ${ }^{23}$

This is where Spain enters the picture. After forty years of authoritarian Hispanic political idiosyncrasy, Spaniards had, without a doubt, a desire for Europe. Joining the EC had become an aspiration of the Spanish political class to break with what was considered an anomalous parenthesis on the European side of Spain's history. And, after the rigors of the accession negotiations, which began

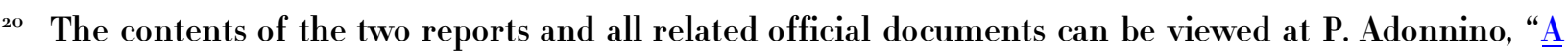
People’s Europe. Reports from the ad hoc Committee“, Bulletin of the European Communities, Supplement $7 / 85$ $\left(\text { I9 }_{5}\right)^{\text {I- }} 35$.

2i Adescription of the events that took place on the occasion of the first Europe Day and the adoption of the new European flag and anthem can be found at Commission of the EC, "European Identity: Simbols to Sport", European File n. $6 / 8_{7}\left(\mathrm{Ig}_{7}\right)_{\text {) }} \mathrm{I-12}$, at 3 .

${ }_{22}$ In particular, freedom of movement and residence in any country of the Union, the right to vote and to stand as a candidate in local and European elections held in the country of residence even if it is not the country of origin, diplomatic and consular protection from the authorities of any Member State in countries where the state of which you are a national is not represented, the right to petition and the establishment of a European ombudsman.

${ }_{23}$ “You don't fall in love with a Common Market, you need something else”. Quoted in Th. Kuhn, “Nobody falls in love with a Common Market': Why Cross-border Interactions Don't Always Foster European Identity“, The UACES Blog, November 2013. 
in 1979, on I January 1986, under the government of Felipe González, Spain effectively became a member of the EC.

Those of us who had the opportunity to listen to the speech González was invited to give at the opening ceremony of the $1985^{-19} 86$ academic year in one of the temples of academic Europeanism, the College of Europe in Bruges, were able to confirm his certainty about the decidedly Europeanist character of the Spanish people which led him to believe that Spain could "constitute a positive factor for the indispensable reforms of the European Community". ${ }^{24}$

We were soon able to check it out. Those who have been called the "Golden Years" of Spain's membership of the EC, from its accession until 1992, saw our country become one of the most determined defenders of the Economic and Monetary Union, and of the Political Union. ${ }^{25}$ And this attitude led, in the months prior to the formal convening of the Intergovernmental Conference that would approve the Maastricht Treaty, ${ }^{26}$ to the drafting of a memorandum entitled "Towards a European citizenship”. The memorandum proposed the creation of European citizenship as a "personal and inseparable status of the nationals of the Member States, who by virtue of their membership of the Union are subject to special rights and duties within the Union" ${ }^{27}$

In honesty, we have to admit that the Spanish proposal was nothing new in terms of its content. It was basically limited to taking up the measures advanced by the Adonnino Committee and little else. However, it had the virtue of embodying, on a symbolic level, the spirit of that "Europe of the peoples" which had become so fashionable. To such an extent that, despite British and Danish reticence, European citizenship ended up being part of the Maastricht Treaty which introduced Articles 8 to $8 \mathrm{E}$ into the EC Treaty under the heading "Citizenship of the Union". Overnight, we all became European citizens.

The Treaty of Maastricht set the definitive traits of this new addition to Community law. ${ }^{28}$ The most important is undoubtedly its derivative character: to be a citizen of the Union you have to be a national

${ }_{24}$ In French in the original. Translation is mine. The full text of the speech is available at https://www.coleurope.eu/events/opening-ceremony-bruges-campus-2I.

${ }_{25}$ See C. Powell, "Fifteen years on: Spanish membership in the European Union revisited", Center for European Studies Working Paper No. 89 (200I) I-I8, at 2.

${ }_{26}$ Atour of the backroom that led to the Maastricht Treaty can be seen at F.J. Fonseca \& J.A. Martín, “La Unión Europea: génesis de Maastricht“, 19 Revista de Instituciones Europeas (1992) 517-563.

${ }_{27}$ The Memorandum divided the rights of future European citizens into three classes: special basic rights (freedom of movement and residence, and participation in political life); new “dynamic” rights (those that could be derived from the evolving nature of the EC, incorporating over time new social, environmental and cultural rights); and rights to "protection" (diplomatic and consular protection and ombudsman). The measures contained in the document would be incorporated as a formal proposal in a letter from the President of the Spanish Government to the President of the European Council, and the proposal would be further refined on $2 \mathrm{I}$ February 199.. See Mindus supra n. I5, at ı.

${ }_{28}$ The specific content of the new institution, in the form of rights associated with the status of citizen, was basically the same as those we saw earlier in the Adonnino Committee Reports: the right to move and reside freely within the territory of the Member States; the right to vote and stand as a candidate in municipal elections and in elections to the European Parliament in the Member state in which one resides; the right to enjoy, in the territory of a third country in which the Member state of which one is a national is not represented, the protection of the diplomatic and consular authorities of any Member state; the right to petition the European Parliament; and the right to apply to the Ombudsman newly established by the Maastricht Treaty itself. See A. Rallo, "Los derechos de los ciudadanos europeos”, I8 Revista de la Facultad de Derecho de la universidad Complutense (I994) 25-276; A. Mangas, “Título V Ciudadanía”, in A. Mangas (dir.), Carta de los Derechos Fundamentales de la Unión Europea: 
of a Member State. ${ }^{29}$ As citizenship was directly linked to the concept of nationality,${ }^{30}$ which touches directly on the hard core of the powers of the modern Westphalian State, the Member States took it upon themselves to make it clear, in a Declaration annexed to the Final Act of the Maastricht Treaty, that "the question whether an individual possesses the nationality of a Member State shall be settled solely by reference to the national law of the Member State concerned”. It was clear that the new EU was not going to go around happily handing out citizenship cards to those whom it saw fit.

Over time, the European citizenship underwent some minor cosmetic touches. The Treaty of Amsterdam, in I997, renumbered the articles of the Treaty establishing the EC devoted to citizenship from 17 to 22 . It also added that citizenship of the Union would be complementary to, and not a substitute for, national citizenship. In 2ooo, the Charter of Fundamental Rights of the European Union, in Articles 39 to 46 , reiterated the rights of European citizens, extending the scope ratione personae of the majority, except for the political ones, to cover third-country nationals legally resident in the Union. Finally, the Treaty of Lisbon carried out a final renumbering of the articles of European citizenship, which became Articles 20 to 25, while amending the proviso added to the Treaty of Amsterdam to read "Citizenship of the Union shall be additional to and not replace national citizenship".

In terms of its specific content, the new European citizenship brought almost nothing new to the list of rights already enjoyed by nationals of the Member States. Besides, it entailed no obligations, and its impact had all the hallmarks of being extremely limited in the day-to-day life of the new European citizens. Some did not hesitate then to describe it as a "cynical exercise in public relations", ${ }^{31}$ a "pie in

Comentario artículo por artículo (Fundación BBVA, Bilbao, 2008) 645, at 65o; J. Martínez, "La ciudadanía de la Unión Europea y sus derechos: un análisis crítico”, en 23 Revista de Derecho UNED (2018) 423-456; J.A. González, "Ciudadanía europea”, in R. Reyes (dir.), Diccionario crútico de Ciencias Sociales (Ed. Plaza y Valdés, MadridMéxico, 2009).

${ }_{29}$ See P. Solbes, "La citoyenneté européene”, 345 Revue du Marché Commun et de l'Union Européenne (I99i) ı68-I7o; and J.L. Gil, "La vinculación de la ciudadanía europea a la nacionalidad“", 39 Revista El Notario del Siglo XXI (20II).

$3^{\circ}$ Citizenship and nationality are like two sides of the same coin. Nationality refers to the legal bond that unites a person with a state, through which that person is under the personal jurisdiction of that state. In Nottebohm, the International Court of Justice defined it as a "legal bond having as its basis a social fact of attachment, a genuine connection of existence, interests and sentiments, together with the existence of reciprocal rights and duties". Liechtenstein $v$ Guatemala - Nottebohm - Judgment of 6 April 1955 - Second Phase, ICJ Reports (1955), 4, at 23 . In international law the term citizenship also refers to the same legal bond and is in fact used interchangeably with nationality. Some states differentiate, however, between the two, citizenship being used to describe the political, social, cultural, local and linguistic aspects of domestic law of that same bond, or the set of rights that the national of a State may exercise. See W.T. Worster, "Brexit and the Intern ational Law Prohibition on the Loss of Nationality", I5 International Organization Law Review (2018) 341-363, at 343 [doi:Io.II63/15723747-0I502005]. In Communitylaw, it is clear that "nationality" refers to that formallinkbetween a person and a state, while the term citizenship refers to the new status created in Community law. A tour of the meanings of both terms in the different Member States can be seen in G.R. De Groot, "Towards a European Nationality Law", 8 Electronic Journal of Comparative Law (2004) I-37, at 2.

$3^{3^{\mathrm{r}}}$ J.H.H. Weiler, "European Citizenship and Human Rights", in A.E. Kellermann et al (eds), Reforming the Treaty on European Union: The Legal Debate (Kluwer, The Hague, (1996) 68. 
the sky", ${ }^{32}$ a symbolic device to camouflage the lack of real developments in the field of social rights, ${ }^{33}$ a "blank banner" or a "mobilizing metaphor". ${ }^{34}$

To understand, however, the exact content and implications of European citizenship by looking at its constituent articles is, as scholars of Community law know, an incomplete exercise. In the Union's legal order, more than in others, it is always necessary to scrutinize very closely the interpretations of it made by the CJEU. Since the beginning of its existence, the CJUE has been characterized by an interpretation of the founding Treaties that is close to Europeanist judicial activism. To the extent that, in the graphic expression used by some authors, legal institutions whose content, according to the Treaties, could be branded as innocuous or irrelevant end up being, in the hands of the CJEU, a veritable pandora's box whose opening releases the most varied Europeanist furies..$^{35}$

\section{(C) THE COURT OF JUSTICE AND EUROPEAN CITIZENSHIP}

At an age, and in circumstances where the staunch defense of the EC's integration project was taken for granted, one could only fantasize, following the study visit that the students of the IEE made to the headquarters of the CJEU (at that time, the CJEC ), about this "phalange judiciaire" ${ }^{6}{ }^{6}$ which, from its Palace in Luxembourghad “judicially revolutionized” the EC. Signing, among others, judgments such

$3^{32}$ H.U. Jessurun D'oliveira, “Union Citizenship: Pie in the Sky?”, in A. Rosas \& E. Antola, E. (eds), A Citizen’s Europe. In Search for a New Order (Sage, London, 1995) 84. It seems that Professor Jessurun has since changed his mind radically. See H.U. Jessurun D'oliveira, "Union Citizenship and Beyond“, EUI Working Paper LAW 20I8/15 (2018) I-I9, at 2 [doi:Io.2139/ssrn.324768I].

33 See E. Meehan, "Political Pluralism and European Citizenship", in P.G. Lehning \& A. Weale. (eds), Citizenship, Democracy and Justice in the New Europe (Routledge, London, 1997) 69.

${ }_{34}$ See C. Shore, "Whither European Citizenship? Eros and Civilization Revisited", ${ }_{7}$ European Journal of Social Theory (2004) 27-44, at 3I [doi:I0.II77/13684310040400I8].

35 See S. Besson \& A. Utzinger, "Introduction: Future Challenges of European Citizenship. Facing a WideOpen Pandora's Box”, ${ }_{3} 3$ European Law Journal (2007) 573-59o [doi:Io.IIII/j.I468-o386.2007.00384.x].

$3^{6}$ The expression, which today would no doubt be considered very politically incorrect, comes from one of the presidents of the CJEU, Robert Lecourt. Quoted in A. Vauchez, "À quoi «tient» la Cour de Justice des Communautés Européennes? Stratégies commémoratives et esprit de corps transnational”, 6o Revue française de science politique (2010) 247-270, at 254 [doi:10.3917/rfsp.602.0247]. About Lecourt and its legal philosophy, see W. Phelan, "The Revolutionary Doctrines of European Law and the Legal Philosophy of Robert Lecourt", 28 European Journal of International Law (2017) 935-957 [doi:10.2139/ssrn.29or943]. Alongside Lecourt, there are mythical names such as Monaco, Trabucchi, Donner, Catalano, Capotorti, Pescatore, Mertens de Wilmars, Roemer, Verloren van Themaat, and also other actors such as Michel Gaudet, head of the Commission's legal service, and Walter Hallstein, its president from ${ }_{195} 8$ to ${ }_{1967}$, who, according to some, promoted the idea that because the lack of political impetus for European integration at that time, the CJEU had to take the lead in the European integration process by using the law. See also from the same author A. Vauchez, Brokering Europe: Euro-Lawyers and the Making of a Transnational Polity, Cambridge University Press, Cambridge, 2015) 129. 
as Van Gend \& Loos or Costa c. Enel, ${ }^{37}$ which for some had de facto "constitutionalized" the Community legal order, making it more supranational and less intergovernmental. ${ }^{8}$

This use of the law to advance European integration, the famous "integration through law", ${ }^{39}$ caused and still causes, ${ }^{4^{\circ}}$ enormous academic interest. Ignoring however the debate on whether the panEuropean activism of the CJEU is more apparent than real, ${ }^{\text {it }}$ what seems clear is that, despite the criticism it raises, ${ }^{42}$ its role as driving force of European integration did not end in the so-called "Age

37 These two judgments establish, respectively, the direct effect of Community law and its supremacy over national law. Both have literally made rivers of ink flow. A review of all the literature on Van Gend in Loos on the occasion of the $5^{\text {oth }}$ anniversary of his adoption can be found at M. Rasmussen, "Revolutionizing European law: A history of the Van Gend en Loos judgment", I2 International Journal of Constitutional Law (2014) 136-I63 [doi.org/Io.ıo93/icon/mouoo6]. The expression "revolution judiciaire" in relation to these sentences is used by Vauchez, À quoi «tient»..., cited in previous note, at 253.

$3^{8}$ Weiler's article, “The Transformation of Europe”, , oo Yale Law Journal (I99I) 2403-2483, is considered by some to be the standard account of the constitutionalization of the Community order carried out by those two judgments, and obviouslycontains a good presentation of them. See A. Stone, "The European Court of Justice and the judicialization of EU governance”, 5 Living Reviews in European Governance (2010) I-50, at I6 [doi: I0.I2942//reg-20I0-2]. In any case, the first to speak of a constitutionalization was the American professor Eric Stein who published an article in $198 \mathrm{I}$, in 75 American Journal of International Law entitled "Lawyers, Judges and the Making of a Transnational Constitution” (I98I) I-27 [doi:Io.2307/220I/13]. A critical and revisionist vision in relation to the "constitutionalization" of the community legal order can be seen in M. Rasmussen \& D. Martinsen, "EU Constitutionalisation Revisited - Redressing a central assumption in European studies”, 25 European Law Journal (20I9) 25I-272 [doi:ıo.IIII/eulj.ı23I7]. The German Constitutional Court judge Dieter Grimm, taking into account the impact of the jurisprudence of the European Court of Justice on legislative policy, and the difficulty of reversing that jurisprudence due to the need for unanimity to reform the treaties, even speaks of an "overconstitutionalisation” of the EU legal order. See D. Grimm, Europa ja - aber welches? Zur Verfassung der europäischen Demokratie (C.H.Beck, München, 20I6), at I. Grimm does not consider that the community order is still fully constitutional due to the absence of a "constitutional moment” to ensure its popular legit imacy. See D. Grimm, “The Democratic Costs of Constitutionalisation: The European Case”, 2 I European Law Journal (20I5) 460-473[doi:ıo.nII/eulj.ı2I39].

39 From the name of the project that, under the same title, was carried out during the I98o's at the European University Institute in Florence by professors Mauro Cappelletti, Monica Seccombe and Joseph Weiler. On the history of the project and its repercussions to this day you can read R. Byberg, "The History of the Integration Through Law Project: Creatingthe Academic Expression of a Constitutional Legal Vision for Europe”, I8 German Law Journal (2017) I53'-I556 [doi:ıo.IoI7/S207I8322000224Io]; and L. Azoulai, “Integration through law' and us”, I4International Journal of Constitutional Law (2016) 449-463 [doi:Io.rog3/icon/mowo24].

$4^{\circ}$ According to Stone Sweet, the CJEU is the second most studied jurisdiction by the American doctrine after its Supreme Court. See A. Stone Sweet, “The European Court and Integration”, in A. StoneSweet (ed), The Judicial Construction of Europe (Oxford University Press, Oxford, 2004), at 7 [doi:ro.ro93/or9927553x.oo3.0oor]. The interest is not limited only to legal disciplines. Political science and history have also shown interest in the CJEU. A tour of this literature can be found at L. Conant, "Review Article: The Politics of Legal Integration”, 45 Journal of Common Market Studies (2007) 45-66 [doi:ıo.III/j.I468-5965.2007.00734.x]; and M. Blauberger \& S. Schmidt, "The European Court of Justice and its political impact”, 4o West European Politics (20I7) 907-9I8 [doi:ıo.ıo80/oI/02382.2017.12816 $5_{52}^{2}$.

$4^{1}$ For some, this activism is more apparent than real and, deep down, the jurisprudence of the CJEU is constantly aligned with the interests of the Union's major powers. See the literature cited in the previous note.

$4^{2}$ The pioneer in questioning the consensus on the positive role played by the CJEU in the European integration process was undoubtedly the Danish jurist Hjalte Rasmussen with his pioneering work On Law and Policy in the European Court of Justice: A Comparative Study in Judicial Policymaking, published in 1986 by Martinus Nijhoff. As a lover of controversy as I am, I cannot help but acknowledge that Professor Rasmussen's provocative and entertaining style made me a convert to his theses duringmy time at the College of Europe where 
d'or" of the Luxembourg Court in the I960s.33 Its case law on European citizenship, without which it is impossible to understand the contours and limits of the institution, is good proof of this.4t

The first warning to seafarers of the pro-integrationist potential that European citizenship could acquire at the hands of the CJEU comes even before its entry into force. In Micheletti, ${ }^{\text {t5 }}$ the CJEU decided that the determination of acquisition and loss of nationality is, in accordance with international law, a matter for each Member State. However, this competence must be exercised in compliance with Community law. ${ }^{4}$ The Court thus opened the possibility of introducing limitations on the sacrosanct exclusive competence of the states concerning the determination of their nationals.

Micheletti sparked a lively doctrinal debate about what those limitations might be ${ }^{47}$. But, after all, the events took place before the entry into force of European citizenship, and the legal doctrine it contained was directly linked to the exercise of one of the fundamental freedoms provided for in the founding treaties..$^{8}$ There was therefore a typically community cross-border element that justified the Court's decision to limit state power in the interest of a homogeneous interpretation of Union law.

In Grzelzyk, ${ }^{49}$ on the other hand, the provisions on European citizenship were already in force, were in fact invoked in the preliminary ruling that gave rise to the case, and were expressly used by the CJEU

he was in charge of the course "Constitutional Law-making by the judiciary as a generator of social change".

43 See Vauchez, À quoi «tient»..., supra n. 36, at 254

í See D. Sarmiento, “A vueltas con la ciudadanía europea y la jurisprudencia expansiva del Tribunal de Justicia, 26 Revista española de derecho europeo (2008) 2II-227; E. Crespo, "La jurisprudencia del TJCE en materia de ciudadanía de la Unión: una interpretación generosa basada en la remisión al derecho nacional y en el principio de no discriminación por razón de la nacionalidad”, 28 Revista de Derecho Comunitario Europeo (2007) 883-912.

45 Judgment of the Court of 7 July r992, Mario Vicente Micheletti and others v Delegación del Gobierno en Cantabria, Case C-369/9o, ECLI:EU:C:I992:295. The facts giving rise to the question referred for a preliminary ruling occurred in March r99o: the Spanish government delegation in Cantabria refused to grant a residence card to Mario Vicente Micheletti, an Argentine dentist who also held Italian nationality, on the grounds that, in accordance with the Spanish civil code, which itself respects international law, in cases of dual nationality the one which prevails is that of the state in which one had habitual residence prior to arrival on Spanish territory, in this case Argentina.

$4^{6}$ In particular, the CJEU said that it was not for the law of a Member State to limit the effects of conferring the nationality of another Member State by requiring additional conditions for recognizing that nationality in order to exercise the fundamental freedoms provided for in the Treaty. An interpretation of Article $5^{2}$ of the Treaty, according to which, where a national of a Member State is also a national of a third country, the other Member States may make recognition of his or her Community citizenship subject to conditions such as the person's habitual residence, could lead to a divergent interpretation of Community law in the various Member States. See M. Fraile, “La ciudadanía europea”, 7 Fundamentos: Cuadernos monográficos de teoría del estado, derecho público e historia constitucional (2012) $3^{10-357}$, at $3^{16-320 . ~}$

47 See M. Hailbronner \& S. Iglesias, "The European Court of Justice and Citizenship of the European Union: New Developments Towards a Truly Fundamental Status", 5 Vienna Journal on International Constitutional Law (20II) 498-537, at 506 [doi:Io.I5I5/icl-20II-0403].

${ }_{4}^{8}$ SeeS. Alonso, “Elinminente tránsito hacia una ciudadanía supranacional de la UE”, ${ }_{7}$ Cuadernos Europeos de Deusto (2012) IоI-126, at II6 [doi.org/10.I8543/ced-47-2012ppIoI-I26].

49 Judgment of the Court of 20 September 2ooI, Rudy Grzelczyk v Centre public d'aide sociale d'OttigniesLouvain-la-Neuve, Case C-184/99, ECLI:EU:C:20oI:458. The case concerns a student of French nationality, Mr. Grzelczyk, who began his university studies in Belgium. At the beginning of his fourth and final year of studies, he applied to the Belgian government for an assistance benefit which was granted and subsequently withdrawn, as he did not fall within the definition of a worker under secondary law. The Court of Justice held that the provisions relating to non-discrimination and European citizenship preclude the grant of a social benefit under 
to settle the case..$^{\circ}$ In any event, there was still a cross-border element in this case, which directly connected it with the exercise of fundamental freedoms. Citizenship was therefore not the only legal basis whose autonomous effects made it possible to resolve the issue. Its importance, however, resides more in the obiter dictum that it contains, connected with expressions of the same style that have marked the Court's Europeanist activism: "Union citizenship is destined to become the fundamental status of nationals of the Member States".

From then on, the expression would become commonplace in the Court's main jurisprudence on citizenship. ${ }^{5^{1}}$ A clear warning that the best was yet to come. Baumbast,,$^{5^{2}}$ for example, concerned a person who had previously exercised one of the fundamental freedoms provided for in the Treaties, although he had ceased to do so. The Court began to decouple the effects of citizenship from the exercise of economic activities, and clearly stated that the Treaty on the European Union did not require European citizens to be employed or self-employed in order to enjoy the rights relating to citizenship, including the right of residence in any country of the Union.

But it is in Rottman and Ruiz Zambrano that the CJEU unashamedly displays the potential supranational effects of European citizenship. In the first case, ${ }^{53}$ the CJEU, which had left us in doubt in Micheletti as to what limits Community law could impose on the state's competences to determine its nationals, gives us the first of these.

Janko Rottman was initially, by birth, an Austrian national. He later moved to Germany to escape criminal proceedings against him in Graz, Austria, and an arrest warrant was issued. In Germany he applied for and obtained German nationality, without mentioning the criminal proceedings in which he was involved. Obtaining German nationality resulted, under Austrian law, in the loss of Austrian nationality. When the Austrian authorities informed the Germans that Rottman was the subject of

a non-contributory scheme from being made subject to a condition which nationals of the host Member State are not required to meet.

$5^{\circ}$ Earlier, although less forcefully, the CJEU had cited European citizenship in the Judgment of the Court of I2 May I998, María Martínez Sala v Freistaat Bayern, Case C-85/96, ECLI:EU:C:1998:2 I7; and the Judgment of the Court of 24 November 1998, Criminal proceedings against Horst Otto Bickel and Ulrich Franz, Case C-274/96, ECLI:EU:C:I998:563.

${ }^{5^{\mathrm{I}}} \quad$ A list of all judgments referring to citizenship up to 2007 can be found at F. Wollenschläger, “The Europeanization of citizenship. National and Union citizenships as complementary affiliations in a multi-level polity“, Paper presented at the EUSA Tenth Biennial International Conference, Montreal, Canada, I7 May 2007 , I-I3.

$5^{2}$ Judgment of the Court of 17 September 20o2, Baumbast and $R \mathbf{v}$ Secretary of State for the Home Department, Case C-413/99, ECLI:EU:C:20o2:493. The facts relate to the Baumbast family who were validly resident in the United Kingdom because of the husband's economic activity. Following their separation, and the loss of worker status by Mr Baumbast, the English Government refused to grant a residence permit to all the members of the family, on the ground that their health insurance did not cover emergency medical care, and that they were a burden on the English exchequer within the meaning of a Community directive. The Court said that a citizen of the European Union who no longer enjoys a right of residence as a migrant worker in the host Member State may, as a citizen of the Union, enjoy a right of residence in that State by virtue of the direct application of Article I8(I) EC. The exercise of that right is subject to the limitations and conditions referred to in that provision, but the competent authorities and, where appropriate, the national courts must ensure that th oselimitations and conditions are applied in compliance with the general principles of Community law and, in particular, the principle of proportionality, a principle which was not observed in this case.

53 Judgment of the Court (Grand Chamber) of 2 March 2oı,, Janko Rottmanv Freistaat Bayern, Case C-I35/o8, ECLI:EU:C:20I0:104. 
criminal proceedings, his naturalization was revoked retroactively on the grounds that he had obtained German nationality by fraud.

Perhaps because it touches on the hard core of sovereignty, the law on nationality, both the states involved in the case and the Commission agreed that this was a purely internal situation that had no link with Union law. The CJEU saw things differently and made it clear that, even in the absence of cross-border movements, national measures depriving an individual of Union citizenship status, and associated rights (as was the case when the withdrawal of German nationality meant that Rottman became stateless), fell within the scope of the Treaties. In other words: Member States could no longer deprive anyone of their nationality without the supervision of the GJEU, by virtue of the expansive nature of European citizenship..$^{54}$

In Ruiz Zambrano the CJEU took another great step forward, introducing one more of those indeterminately mysterious concepts that make the members of the academy so happy: the substance of the rights conferred by the status as citizen of the Union. ${ }^{55}$ In this case, the Court had to decide whether a Colombian national, who was illegally resident in Belgium, could obtain, on the basis of the provisions of the treaty on citizenship, residence and work permits because he was the father of two children with Belgian nationality who had never left the territory of that Member State.

Against all odds - the governments involved, and the Commission regarded the situation as strictly internal— the CJEU decided that Ruiz Zambrano should receive not only a residence permit but also a work permit. Why? Because, otherwise, his children, who were citizens of the Union, would be deprived, as they would probably have to leave Belgium, of the effective enjoyment of the substance of the rights attached to citizenship status.

The sentence raised great academic dust and, considering that it affected an illegal immigrant, also a political one. ${ }^{6}$ The most pro-integrationist considered that the two rulings advanced the legal construction of citizenship of the Union in a quasi-federal direction, independent of any cross-border movement or underlying economic logic. This was for many a welcome constitutional development of European citizenship. ${ }^{57}$

54 The Court refers to Micheletti - the determination of the ways in which nationality is acquired and lost is, in accordance with international law, a matter for each Member State. But specifies that the situation of a Union citizen who, like the applicant in the main proceedings, is faced with a decision revoking naturalization taken by the authorities of a Member State which places him, after having lost the nationality of origin of another Member State, in a position which may result in the loss of the status conferred by Article 17 EC and the corresponding rights is, by its very nature, within the scope of the law of the Union to be respected. In the present case, although it is legitimate for a state to take measures, such as the revocation of the grant of nationality where it has been obtained under fraudulent conditions, Community law requires that those measures comply with the principle of proportionality, something which did not occur in this case when Rottman became stateless.

55 Judgment of the Court (Grand Chamber) of 8 March 2oIr, Gerardo Ruiz Zambrano v Office national de l'emploi (ONEm), Case C-34/og, ECLI:EU:C:201ı:ı24.

${ }_{5^{6}}$ Shaw speaks of Member States' dismay at the possible effects of the judgment. See J. Shaw, "Has the European Court of Justice Challenged Member State Sovereignty in Nationality Law?”, 62 EUI Working Papers (20II) I- 5 I, at 33 .

57 Hailbronner \& Iglesias, supra n. 47, at 5 OI. 
Others, along the lines of Joseph Weiler, who warned in 2oor that the Court's reasoning tended to be too Cartesian, ${ }^{5}$ considered the argument laconic, cryptic, minimalist, even poor. ${ }^{59}$ Some revived the traditional accusations of ambivalence, lack of coherence and legal basis, and irrationality. ${ }^{60}$ One author openly spoke of judicial error. ${ }^{6 r}$

Such were some of the criticisms that CJEU President Koen Lenaerts himself had to come out to the forum to explain that they were following an incremental approach to dealing with issues of potential constitutional importance. According to him, if one followed the evolution of the case-law on questions of citizenship, as he did in his article with Ruiz Zambrano, its background and its aftermath, it was quite clear that the CJEU was following a "step-by-step” method, respectful of the nature of preliminary ruling questions, common in the Anglo-Saxon courts. Hence, it could not be accused of being laconic or cryptic at all. ${ }^{6}$

One cannot help thinking that academic criticism, and, above all, political concerns, must have made some dent in the direction taken by the case law on citizenship from that moment on. If one analyses the judgments that followed Ruiz Zambrano, ${ }^{6}$ it becomes clear that the doctrine of effective enjoyment of the substance of the rights linked to the status of citizen only operates in exceptional circumstances: when the national provision in question forces the citizen to leave the territory of the Union, thus depriving him/her of the effective enjoyment of his/her rights.

${ }_{5}^{8} \quad$ J.H.H. Weiler, "Epilogue: The Judicial après Nice”, in G. De Búrca \& J.H.H. Weiler. (eds), The European Court of Justice (Oxford University Press, Oxford, 200I) 215, at 225.

59 K. Hailbronner \& D. Thym, "Case C-34/og, Gerardo Ruiz Zambrano v. Office national de l'emploi (ONEm), Judgment of the Court of Justice (Grand Chamber) of 8 March 20II", 48 Common Market Law Review (201I) ${ }_{2} 53^{-}$ I270; and U. Šadl, "Case - Case-Law - Law: Ruiz Zambrano as an Illustration of How the Court of Justice of the European Union Constructs its Legal Arguments", 9 European Constitutional Law Review (2013) 205-229, at $205^{-}$ 209. [doi:10.1017/Si57401961200II25].

6o SeeA. Somek, “Is Legality a Principle of EU Law?", in S. Vogenauer \&.S. Weatherill(eds), General Principles of Law European and Comparative Perspectives (Hart Publishing, Oxford, 2017); K. Hailbronner, "Die Unionsbürgerschaft und das Ende rationaler Jurisprudenz durch den EuGH?”, 57 Neue Juristische Wochenschrift (2004) 2185-2188; D. Martin, "Comments on Mazzoleni (ex parte Guillaume) (Case C-165/98 of I5 March 200I), Leclere (Case C-43/99 of 3 I May 20or) and Grzelczyk (Case C-184/99 of 20 September 20or)”, 4 European Journal of Migration and Law (2004) $\mathrm{I}_{2} 7^{-\mathrm{I}} 44_{4}$, at $\mathrm{I}_{3}$. Some even consider that, under the guise of a certain pro-European goodism, which leads to the Europeanisation of what were exclusively national competences for the sake of citizenship, the GJEU is inadvertently giving a coup de grace to the underlying logic of the welfare state, and with it, to the social rights of all. See A.J. Menéndez, "European Citizenship after Martínez Sala and Bambaust. Has European law become more human but less social?", iI ARENA Working Paper (2009) I-41, at 3 8-39.

${ }_{61}$ See H.U. Jessurun D'oliveira, G.R. de Groot \& A. Seling, "Court of Justice of the European Union: Decision of 2 March 2010, Case C-3I5/o8, Janko Rottman v. Freistaat Bayern Case Note I Decoupling Nationality and Union Citizenship? Case Note 2 The Consequences of the Rottmann Judgment on Member State Autonomy - The European Court of Justice's Avant-Gardism in Nationality Matters", 7 European Constitutional Law Review (20II) I38-16o [doi:10.ıог/Si5740196rirooo73].

${ }^{6}$ See K. Lenaerts, "EU citizenship and the European Court of Justice's 'stone-by-stone' approach", I International Comparative Jurisprudence (2015) I-10, at 9 [doi.org/IO.IoI6/j.icj.2015.10.005].

${ }_{6}$ Cases McCarthy, Dereci, $O$ \& $S$, Imeraga y Alokpa. See the comments on those cases made by Lenaerts himself in the article cited in the previous note. 
But it will be, above all, Dano ${ }^{6_{4}}$ and Alimanovic $^{6_{5}}$ where we could see, according to some, the beginning of a "regression" in the case law of the CJEU on citizenship. ${ }^{66}$ In both cases, the CJEU underlines that Union citizens can claim non-discriminatory treatment only if they are legally resident in the host Member State, i.e., if they fulfil the conditions for residence as laid down in Directive $2004 / 3^{8}$ on the right of citizens of the Union and their family members to move and reside freely within the territory of the Member States. For some, a return to determining the rights of individuals based on their belonging to one of the categories established in secondary law, rather than a holistic view of the concept of citizenship.

Regression or not, what is clear is that the case law of the CJEU, since the European status civitatis depends on the nationality of the Member States, has ended up having repercussions on the hard core of the competences of the modern state, i.e., determining who its nationals are and, therefore, the holders of the rights that it has to respect and the obligations that it can demand. These are powers that the Member States themselves had wanted to safeguard specifically in the above-mentioned Declaration annexed to the Maastricht Treaty.

For this reason, the most Europeanist scholars also thought of the CJEU, together with international law, as one of the bastions that could put limits on the loss of citizenship rights because of Brexit. It is therefore time to make a leap in European citizenship towards a doctrinal vision of it. In fact, some have even argued that it is impossible to understand the evolutionary vicissitudes of the institution, including the case law of the CJEU, without taking into account an academia that, seeing an enormous potential in the evasive phrases of the Treaties, pressed to give it the form that best suited its socio-legal preferences. ${ }^{67}$

${ }_{64}$ Judgment of the Court (Grand Chamber), in November 201/4, Elisabeta Dano and Florin Dano v Jobcenter Leipzig, Case C-333/13, ECLI:EU:C:201/2358. In Dano the CJEU had to determine whether a Romanian national resident in Germany who was not engaged in any economic activity and whose period of residence in the host Member State was more than three months but less than five years (i.e. who did not fulfil the conditions of secondary entitlement to social benefits in the host country), could rely on equal treatment with nationals of the latter Member State as regards entitlement to social benefits. The Court established that the possible existence of unequal treatment between Union citizens who have made use of their freedom of movement and residence and the nationals of the host Member State as regards the granting of social benefits is an inevitable consequence of Directive $200_{4} / 38$, based on the requirement of sufficient resources as a condition of residence, on the one hand, and the concern not to create a burden on the social assistance of the Member States, on the other. Therefore, a Member State should have the possibility, under Article 7 , to refuse social benefits to Union citizens who do not exercise an economic activity and who exercise their freedom of movement for the sole purpose of being able to benefit from the social assistance of another Member State when they do not have sufficient resources to qualify for the right of residence.

${ }_{5}$ Judgment of the Court (Grand Chamber) of ${ }_{5}$ September 2015, Jobcenter Berlin Neukölln v Nazifa Alimanovic and Others, Case C-67/14, ECLI:EU:C:2015:597. This case concerns a Swedish national and her children, who are resident in Germany, who have had their living allowances for the long-term unemployed withdrawn on the grounds that their right of residence was based solely on the search for employment and were not therefore covered by German legislation. The Court considered that German law, although it did not apply equally to Germans, was not discriminatory as it was based on secondary law.

${ }_{66}$ See 0. Garner, "The Existential Crisis of Citizenship of the European Union: The Argument for an Autonomous Status", 20 Cambridge Yearbook of European Legal Studies (2018) II6-I 6 , at 127 [doi:ro.ror7/cel.2or8.6]; N. Shuibhne, "Limits rising, duties ascending: The changing legal shape of Union citizenship", $5^{2}$ Common Market Law Review (2015) 889-937; C. O'brien, "Civis Capitalist Sum: Class as the New Guiding Principle of EU Free Movement Rights”, ${ }_{33}$ Common Market Law Review (2016) 937-977.

${ }_{6}$ The academics most committed to the positions apparently supported by the Court demonstrated their 


\section{(D) ACADEMIA, EUROPEAN CITIZENSHIP AND BREXIT}

In the spring of 1986 , I was travelling from Brussels to Florence. My doctoral thesis project had been pre-selected at the Law Department of the European University Institute (EUI), ${ }^{68}$ at that time directed by Mario Cappelletti, with Gunther Teubner as one of the emerging star s. Joseph Weiler had just left it to go to the University of Michigan. If, after the necessary interview with the professors of the Department, my project was finally accepted, which it finally was, the EUI itself would see to it that the Spanish government financed my studies there.

I didn't finish my thesis at the EUI because of the twists and turns of life, but I did spend enough time there to learn a lot from the interesting seminars organized at the Law Department, while witnessing first-hand how an elite research centre operates at the European level. I also enjoyed, of course, the academic social life, looking out from the loggia of the Badia Fiesolana at the incredible views of Italian Tuscany.

Anyone who has been sitting in that loggia, listening to the conversations of the different characters who walk around the EUI headquarters, ${ }^{69}$ can have no doubt that some of the scholars of European law, especially those who revolve around the EUI, form part of what the Anglo-Saxons call "advocacy networks", ${ }^{70}$ and "epistemic communities"..$^{7}$ These are referred to by Vauchez as "cooperation

contribution to a supranational reading of European citizenship, having helped to unfold its Europeanist potential. Without wishing to draw a line between those who were right and those who were wrong, they did state openly that they were much more successful in shaping the socio-legal reality than those who, not having seen that citizenship was not only what it was, but also what it should be, were much less convincing, timid, or directly short-sighted, in helping to unfold the true potential of European citizenship. See D. Kostakopoulo, "Ideas, Norms and European Citizenship: Explaining Institutional Change”, 68 The Modern Law Review (2005) 233-267, at $26_{3}$; and D. Kochenov, "The Essence of EU Citizenship Emerging from the Last Ten Years of Academic Debate: Beyond the Cherry Blossoms and The Moon?", 62 International and Comparative Law Quarterly (2013) 97-136, at 99 [doi:ı.ıor $/$ Soo20 $_{5} 893^{120005} 89$ ]. Both articles contain important reviews of the academic literature on European citizenship. Also J. Shaw, "Citizenship: Contrasting Dynamics at the Interface of Integration and Constitutionalism“, in P. Craig \& G. De Búrca (eds), Evolution of EU Law $\left(2^{\text {nd }}\right.$ ed, Oxford University Pres, Oxford, 20II) 575; Garner, supra n. 66; and, although older, A. Warleigh, "Frozen: Citizenship and European Unification", I Critical Review of International Social and Political Philosophy (1998) I13-15 [ [doi:Io.ıо8о/13698239808403261].

${ }^{68}$ The idea of a European University was first presented at the European Congress in The Hague in I948. But it was not until 1972 that Belgium, France, Italy, Luxembourg, the Netherlands, and Germany signed the Convention that created it outside the institutional apparatus of the EC, but in its orbit. According to Article 2 of the Convention, its main objective is "to contribute, by its activities in the fields of higher education and research, to the development of the cultural and scientific heritage of Europe, as a whole and in its constituent parts. Its work shall also be concerned with the great movements and institutions which characterize the history and development of Europe”. The history of its origins can be seen in J.M. Palayret (ed), A University for Europe: Prehistory of the European University Institute of Florence (1948-76), (Presidency of the Council of Ministers, Department of Information and Publishing/European University Institute, Rome/Florence, 1996).

${ }_{69}$ For an idea of the constant movement between the academic, judicial and bureaucratic world of the EU, which has as its meeting point the EUI, see Byberg, supra n. 39 .

$7^{\circ}$ "A transnational advocacy network includes those relevant actors working internationally on an issue, who are bound together by shared values, a common discourse and dense exchange of information and services". See M.E. Keck \& K. Sikkink, Activist Beyond Borders: Advocacy Networks in International Politics (Cornell University Press, Ithaca, I998), at. 2.

${ }^{7}$ "An epistemic community is a network of professionals with recognized expertise and competence in a particular domain and an authoritative claim to policy-relevant knowledge within that domain or issue-area". See P. Haas, “Introduction: Epistemic Communities and Policy Coordination”, 46 International Organization 
networks" or "support groups" of Community's bureaucratic and judicial world that have built the European Union that we know. ${ }^{72}$ In other words, the most pro-integrationist academic world of European law has not just meekly followed judges and legislators, but has actively helped to shape the Union and its citizenship..$^{73}$

A first important point of his disciplinary energy turned to the legal meaning of the new institution, its nature. It could not be otherwise given the derivative character of European citizenship. The most pro-European academic doctrine analysed European citizenship through cosmopolitan lenses and emphasized the possibility it offered of political membership and individual and collective selfdetermination beyond the borders of the nation state. For them, ${ }^{74}$ the derivative character was a mere determinant of access to status. What was important was that the essence of the institution was totally communitarian in the sense that the rights it granted were totally dissociated from the nationality that had given access to the status. Taking logic to the extreme, some authors proposed disconnecting one and the other in the future, ${ }^{75}$ or, in any case, to extend it to third-country nationals' resident in the territory of the Union..$^{6}$

The discussion on nature was accompanied by the debate on the logic underlying European citizenship. Traditionally, Community law unfolded its effects in the presence of a cross-border logic linked to the existence of a single market. It was the exercise of one of the four fundamental freedoms contained in the Treaties that triggered the application of Community law. In the absence of such a cross-border link, the situation was considered purely internal to the Member state. It is true that the CJEU had interpreted extensively the situations that triggered the Community link, but ultimately a “cross-border element” was needed.

The advent of European citizenship led some to believe that we were faced with a new "fundamental freedom without a market", an extension of the scope ratione materiae and ratione personae of the Treaty. From now on, any citizen of the Union could possibly fall within the scope of Community law without having to be in a cross-border situation linked to an economic activity. ${ }^{77}$ Some even advocated

(1992) I-35, at 3 [doi:10.10I7/Soo2o8I8 $300001 / 42]$.

$7^{2}$ See Vauchez, supra n. 36 , at 249.

73 See D. Kochenov, "The Present and the Future of EU Citizenship: A Bird's Eye View of the Legal Debate", Jean Monnet Working Paper o2/I2 (2012), I-50, at 4-5 [doi:ı.2139/ssrn.20632oo]; J. Shaw, "Constitutional Settlements and the Citizen after the Treaty of Amsterdam”, in K. Neunreither \& A. Wiener (eds), European Integration after Amsterdam: Institutional Dynamics and Prospects for Democracy (Oxford University Press, Oxford, 200o) [doi:10.1093/o198296401.003.00I5].

74 The main exponents can be seen in D. Kochenov, "Ius Tractum of Many Faces: European Citizenship and the Difficult Relationship between Status and Rights", I5 Columbia Journal of European Law (2009) I8I-193.

75 See D. Kostakopoulou, "European Union Citizenship and Member State Nationality: Updating or Upgrading the Link", in J. Shaw, Has the European Court of Justice Challenged Member State Sovereignty in Nationality Law?, EUI Working Papers, RSCAS 20II/62, at. 2Iff.; and Kochenov cited in previous note, at I82. Davis talks about abandoning the hierarchy between European citizenship and nationality in favor of "citizenship pluralism”. See G. Davis, “The EntirelyConventional Supremacy of Union Citizenshipand Rights”, in Sh aw, supra n. 56 , at 9 .

${ }_{7^{6}}$ See D. Kostakopoulou, "EU Citizenship: Writing the Future”, ${ }_{3}$ European Law Journal (2007) 623-646 [doi:Io.IIII/j.I468-0386.2007.00387.x]; E. Balibar, Nous, citoyens d'Europe: Les frontières, l'État, le people (La Découverte, París, 200I), at Igo; A. Føllesdal, "Third Country Nationals as Euro-Citizens - The Case Defended", in D. Smith \& S. Wright (eds), Whose Europe? The Turn Towards Democracy, (Blackwell, London, 1993), at 104-122.

77 See E. Spaventa, "Seeing the Wood Despite the Trees? On the Scope of Union Citizenship and its 
the obligation for host countries to grant social benefits to all migrants who are Union nationals. ${ }^{7}$ Others, taking citizenship based on the exercise of the fundamental freedoms of the common market for granted, began to seek, as a normative exercise, possible alternatives based on values such as justice, equality or political representation. ${ }^{79}$ Some, on the other hand, pointed out that it was too early for triumphalism and that, on close analysis, European citizenship remained closely linked to the market, something which was not particularly negative per se, bearing in mind that the market we are talking about is a market within a constitutionalized order such as the European one. ${ }^{80}$

Another set of questions, linked to the previous one, that drew doctrinal attention was the effect of the new citizenship on the relations between the national and Community legal orders. For some, citizenship came to reshape the federal status quo in Europeby altering the division of powers between the $\mathbf{E U}$ and the Member States. They took, as an example, nationality, whose status as a matter reserved for strict state competence was potentially challenged. ${ }^{{ }^{1}}{ }^{1}$ The most enthusiastic went so far as to assert that European citizenship implied a de facto relativization, if not abolition, of the nationality of Member States. ${ }^{8}$

The remodelling did not end there. As citizenship assumed the end of the connection between transboundary movement and the application of Community law, some authors concluded that no national legislation was potentially outside the scope of the Treaty, ratione materiae. An eventual extension to infinity of the scope of Community law. ${ }^{8_{3}}$

The withdrawal of Great Britain from the European Union has recently enlivened these debates by putting those who defended the quasi-autonomous nature of European citizenship in a paradoxical situation in which, as if by magic, this autonomous link could disappear overnight. In contrast to those who, like me, see the loss of European citizenship, and the very departure from the EU from which it derives, with total legal indifference, ${ }^{84}$ or to those who see it as an inevitable consequence of the practical exercise of democracy, ${ }^{8_{5}}$ those who could be called legalists', or legal romantics', in support of

Constitutional Effects”, 45 Common Market Law Review (20o8) 13-45; F. Wollenschläger, “A New Fundamental Freedom beyond Market Integration: Union Citizenship and Its Dynamics for Shifting the Economic Paradigm of European Integration”, i7 European Law Journal (20II) I-34 [doi:Io.III/j.I468-o386.20I0.00536.x].

$7^{8}$ See the literature cited in N. Shuibhne, "The Resilience of EU Market Citizenship", ${ }_{4}$ Common Market Law Review (2010) I597-I628, at I597-I598.

79 See the literature cited in Kochenov, supra n. 67, at 1o8-ıо9.

8o Shuibhne, supra n. 78 , at 1608 .

${ }_{8}$ See De Groot, supra n. $3^{\text {o. }}$

$8_{2}$ See G. Davies, “'Any Place I Hang My Hat?' or: Residence is the New Nationality”, II European Law Journal (2005) $43-56$, at 43 .

$8_{3}$ See Spaventa, supra n. 77 , at I/4.

$8_{4}$ In line with the argument of the German Federal Constitutional Court in its ruling on the Maastricht Treaty in which, resorting to the key concept in international law of state sovereignty, it made clear that "Germany is one of the 'Masters of the Treaties' who expressed their will to be bound by the indefinitely concluded EU treaty and in this way established a long-lasting membership, which however can be dissolved by an act to the contrary." BVerfGE, I2 October ${ }_{1993}, 89$, II5 $_{5}$ at II2. It is published in Spanish in the 20 Revista de Instituciones Europeas (1993) 975-Io3o. The Court's statement was no less obvious but was criticized by some who seem to regard the EU more as a sect than as an international organization. See C. Rieder, "The Withdrawal Clause of the Lisbon Treaty in the Light of EU Citizenship (Between Disintegration and Integration)", 37 Fordham International Law Journal (2013) I47-174, at 153 [doi:I0.2139/ssrn.3217937].

$8_{5}$ See M. Van den Brink \& D. Kochenov, “Against Associate EU Citizenship”, 57 Journal of Common Market 
a logic based on legal principles and rules, ${ }^{86}$ considered that loss an unacceptable consequence of Brexit from the point of view of law, since it involves a reduction in fundamental rights. ${ }^{87}$ Basically, it was seen as a hard blow to the credibility and reliability of a legal order, that of the Union, hailed at the time as the first concrete example of transnational law. ${ }^{88}$

The legal attack of the "legalists" to try to counteract the foreseeable effects of Brexit on the enjoyment of the rights associated with European citizenship has been articulated around the two legal systems potentially involved: the Union legal order and the international one. With regard to Union law, the lines of argument have revolved, on the one hand, around the consideration that European citizenship is not a status but a fundamental right and, therefore, its withdrawal subject to limitations that would prevent a mass loss of the Brexit type; on the other hand, around proposals for legislative reforms that would mitigate the perverse effects of the loss of the status of national of a Member State. Let us look at them in more detail.

Some authors, based on a pro-integrationist reading of the articles corresponding to European citizenship in the Treaty of Lisbon, the Charter of Fundamental Rights of the Union, and the case law of the GJEU, concluded that citizenship of the Union "acquires the normative quality of a fundamental right, as a general principle of EU law within the meaning of Art. 6(3) TEU, and as a constitutive element of various rights recognized in the Charter" ${ }^{8 g}$ Consequently, as a fundamental right inseparable from personality, the loss of European citizenship through a general measure affecting entire groups of people would be null and devoid of any legal effect. States may leave the Union, but the withdrawal cannot affect citizenship built as a fundamental right within the deep structure of an autonomous legal order such as that of the EU.9.$^{\circ}$

European citizenship would thus acquire a certain autonomous character in relation to the nationality of the Member States. They would still have the competence, but not the right, to grant it via their own nationality, but once acquired they would no longer be free to withdraw it, except by means of an individual measure of a proportionate nature respecting the limits of EU law as set out in the case law of the CJEU..$^{91}$ Taking into account this case law, in particular Rottman and Ruiz Zambrano, and encouraged by the real possibility that the Court might rule on whether the departure of a Member

Studies (2019) I366-I382, at 1376-1378 [doi.org/10.2139/ssrn.3338435].

${ }^{86}$ See J. Shklar, Legalism. Law, Morals and Political Trials (revised ed, Harvard University Press, Cambridge, I986), at I.

$8_{7}$ Examples of the different positions can be seen in Van den Brink \& Kochenov, supra n. $8_{5}$; F. Strumia, "From Alternative Triggers to Shifting Links: Social Integration and Protection of Supranational Citizenship in the Context of Brexit and Beyond", 3 European Papers (2018) 733-759; and D. Kochenov, "EU Citizenship and Withdrawals from the Union: How Inevitable Is the Radical Downgrading of Rights? “, LSE 'Europe in Question” Discussion Paper Series, n. III/20I6, I-39, at 3 ff.

${ }_{88}$ See Strumia, cited in previous note, at $74^{2}$.

${ }^{8}$ See V. Roeben et al, "Protection from Exclusion: A Reassessment of Union Citizenship in the Time of Brexit", Working Paper (2018), at 6 [doi.org/ı.2139/ssrn.3130823].

$9^{\circ}$ Ibid., at I6ff., and M. Dawson \& D. Augenstein, “After Brexit: Time for a further Decoupling of European and National Citizenship?", VerfBlog, 2016/7/14 [doi:Io.17176/2016o71/4-II/4950].

${ }^{91} \quad$ See Rieder, supra n. 87, at I72; Jessurun d'Oliveira, de Groot \& Seling, supra n. 62, at I38ff; W. Worster, "European Union Citizenship and the Unlawful Denial of Member State Nationality", ${ }_{43}$ Fordham International Law Journal (2020) 768-8I8, at 8I6 [doi.org/Io.2139/ssrn.3459635]; and S. Lashyn, "Brexit Means Brexit: Does It so When It Comes to EU Citizenship?”, EJIL:Talk! (2019). 
State from the EU necessarily entails the loss of European citizenship,,$^{92}$ some authors have also begun to speculate on another possible "constitutional moment", of the Van Gend \& Loos type, in which the Court would adopt a decision declaring that European citizenship does not automatically collapse in the event of withdrawal from the Union. ${ }^{93}$

While disciplinary energy was devoted to legal constructions that would shield European citizenship from the effects of a withdrawal from the EU, others were devoted to proposing interpretations of secondary law or legislative changes that would have more or less the same effect. Thus, it has been argued that an analogical interpretation of secondarylegislation would allow English nationals to be considered as "former EU citizens", while maintaining most of the rights contained in Directive 2004/38. ${ }^{94}$ Others argued for the creation of a specially protected EU citizen status for European citizens affected by the Brexit. ${ }^{95}$ Along the same lines, and from the European Parliament, the creation of a new "associated citizenship" was even promoted, which would make it possible to maintain certain fundamental freedoms provided for in the Treaties and to vote in elections to the European Parliament. ${ }^{6}$ Finally, the idea of introducing changes to decouple European citizenship

92 That possibility came close to being realized when a Dutch District Court decided to refer two questions to the CJEU for a preliminary ruling on whether the United Kingdom's withdrawal automatically led to the loss of European citizenship for its nationals and hence of the associated rights and freedoms. The Court of Appeal decided not to refer the questions to the Court on the grounds that they were unspecific and hypothetical at that point in the UK's withdrawal process, but it cannot be ruled out that it may be reactivated in the near future. See in this regard, 0. Garner, "Does Member State Withdrawal from the European Union Extinguish EU Citizenship? C/13/640244/KGZA I7-I327 of the Rechtbank Amsterdam ('The Amsterdam Case')", European Law Blog (2018).

93 See A. Wesemann, "European Union Citizens in Post EU UK”, in K.A. Prinz von Sachsen, J. Garcia \& N. Szuka (eds), Legal Implications of Brexit (MV-W issenschaft, Münster, 20I8) I2 I. For obvious reasons, most authors, while raising the possibility, rule out such judicial activism. See J. Shaw, “EU citizenship: still a fundamental status?", EUI Working Paper, RSCAS 20 18/ı, at 8-9; G. Davies, “Union Citizenship-Still Europeans's Destiny after Brexit?”, European Law Blog (2016); A.P. Van der Mei, “EU Citizenship and Loss of Member State Nationality”, 3 European Papers (20I8) I3I9-I33I, at I327; R. McCrea, "Brexit EU Citizenship Rights of UK Nationals and the Court of Justice“, UK Constitutional Law Association (2018).; Garner, supra n. 92, at 26 ff.; A. Schrauwen, “(Not) losing out from Brexit”, I Europe and the World: a Law Review (2017) I-I8, at 4ff. [doi:I0.I4324/III.444.ewlj.20I7.04]; and Mindus, supra n. I5, at 88.

94 See E. Spaventa, "The impact of Brexit in relation to the right to petition and on the competences, responsibilities and activities of the Committee on Petitions”, Study for the PETI Committee, Policy Department C: Citizens' Rights and Constitutional Affairs, European Parliament (20I7) I-26 [doi:Io.2I39/ssrn.317I/14].

95 “Creating a special EU protected citizen status would ensure that all EU citizens affected by Brexit, that is, EU citizens living in the $U K$ and $U K$ nationals living in the $E U$, would continue to enjoy their EU citizenship rights and to be subject to the same conditions relating to their residence, employment and family reunification which apply to all other EU citizens”. See D. Kostakopoulou, "Scala Civium: Citizenship Templates Post-Brexit and the European Union's Duty to Protect EU Citizens”, $5^{6}$ Journal of Common Market Studies (2018) $8_{54}-869$, at $8_{52}$ [doi.org/IO.IIII/jems.12683].

$9^{6}$ The origins of the proposal can be seen in V. Miller, "Brexit and European Citizenship”, House of Commons Library Briefing Paper, n. $8_{3} 6_{5}$ (2018) I-39, at 24ff.; Van den Brink \& Kochenov, supra n. $8_{5}$, at I366; and V. Roeben et al., "The Feasibility of Associate EU Citizenship for UK Citizens Post-Brexit”, A study for Jill Evans MEP (20I7) I-69 [doi.org/Io.2I39/ssrn.3I78055]. 
from the nationality of the Member States was once again taken up. ${ }^{97}$ It was even suggested, in desperation, that the Member States should naturalize the British..$^{8}$

Even more curious have been the lines of argument that have resorted to international law -in particular to the doctrine of acquired rights, the regime of nationality, and human rights-, seeking limits with which to mitigate the loss of rights associated with European citizenship as a consequence of the Brexit.

Perhaps because of its undeniable legal pedigree, linked to the so-called Theodosian Rule contained in the Digest, that is, the non-retroactivity principle, and to what is generally known as intertemporal law, ${ }^{99}$ one of the first doctrines to be taken out of the keepsake box was that of acquired rights. ${ }^{100}$ Until now, the doctrine had been more widespread in private international law, ${ }^{10}$ and in classical international law, when scholars and some arbitration tribunals used Roman law for their legal arguments. ${ }^{102}$ But it had also moved towards a more contemporary international law. First, through its materialization in article 70 of the 1969 Vienna Convention on the Law of Treaties (VCLT). But also as a legal tool with which to measure some problems linked to the succession of states, and the treatment of foreign investors in cases of nationalizations. Hence, its rescue as a possible brake on the loss of citizen rights associated with Brexit. ${ }^{103}$

97 G. Morgan, 'Union Citizenship for UK Citizens', EUDO Forum Debates Freedom of Movement Under Attack: Is it Worth Defending as the Core of EU Citizenship? (20I6); L. Orgad \& J. Lepoutre, "Should EU Citizenship Be Disentangled from Member States Nationality?", EUI Working Papers, RSCAS 2019/24(2019) I-54 [doi.org/Io.2139/ssrn.3372837].

$9^{8}$ M. Steinbeis, "Nach dem Brexit-Referendum: ein Fast Track zur deutschen Staatsbürgerschaft für bedrohte Unionsbürger!", VerfBlog, 24 June 2016 [doi:ı.17176/2016o624-13I559]; and D. Kochenov., "EU Citizenship and Withdrawals from the Union: How Inevitable is the Radical Downgrading of Rights?“, LEQS Paper No. III/20I6 (20I6) I-32.

99 "Leges et constitutiones futuris certum est dare forman negotiis, non ad facta praeterita revocari, nisi nominatim de praeterito tempore, et adhuc pendentibus negotiis cautum sit". Law 22, Title 3, Book I of the Digest. See B. Verdera, La irretroactividad. Problemática general (Dykinson, Madrid, 20o6).

го The literalness of " to be taken out of the keepsake box " can be verified by taking a cursory look at the bibliography of some of the works that resort to the doctrine of acquired rights. See, for example, M. Waibel, "Brexit and Acquired Rights", III AJIL Unbound Symposium on Treaty Exit at the Interface of Domestic and International Law (2017) 440-444 [doi:Io.Ior7/aju.2017.98]; or A. Fernández \& D. López, "The impact and consequences of Brexit on acquired rights of EU citizens living in the UKand British citizens living in the EU-27", Study for the AFCO Committee, Policy Department C: Citizens' Rights and Constitutional Affairs, European Parliament (2017).

ror See the classic study of A. Miaja, "Los derechos adquiridos en la doctrina española y en el sistema de derecho internacional privado español”, I Anuario de derecho internacional (1974) I-28.

${ }^{102}$ See, for example, the use of it by H. Gros Espiel, "El derecho intertemporal y las formas de adquisición del territorio en el derecho internacional contemporáneo (Primera parte)", Jurídica. Anuario del Departamento de Derecho de la Universidad Iberoamericana, n. I4 $(1982)$ I47-I54; or T.O. Elias, “The Doctrine of Intertemporal Law”, 74 American Journal of International Law (1980) 285-307 [doi.org/10.2307/2201033]. And the classical works of G. Kaeckenbeeck, "La Protection Internationale des Droits Acquis", ${ }_{59}$ Collected Courses of the Hague Academy of

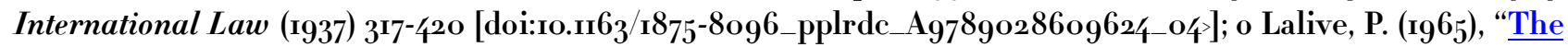
Doctrine of Acquired Rights", in Rights and Duties of Private Investors Abroad.

${ }^{103}$ See the use of acquired rights as a possible limit to the loss of citizenship rights that is made, among others, in Miller, supra n. 96, at I/ff.; Kostakopoulou, supran. 95, at Io; Mindus, supra n. I5, at 62; House of lords (European Union Committee), "Brexit: Acquired Rights. Ioth Report of Session $2016-$ I7”, HL Paper, n. ${ }^{0} 82$ (2016) I- 5 8, at 25 ff.; or F. Strumia \& K.Hadzimusic, (eds), "Brexit and Loss of EU Citizenship: Cases, Options, Perceptions", ECAS Paper (2017) I-29, at I2ff. 
Obviously, the international law doctrine of acquired rights, only by the absurdity of wanting to be applied to a political decision of a democratic character that affects millions of people, did not have much used as a limit to the loss of citizenship rights associated with Brexit, and was soon discarded by almost all commentators. ${ }^{104}$ Eyes then turned to the international law on nationality. ${ }^{105}$

The prospects were not too promising either. State regulation of nationality had traditionally remained outside the scope of international law, in that safety box known as domaine reservée, for obvious reasons. States did not have the slightest interest in self-limitation in a matter, the delimitation of persons subject to their jurisdiction, which, even more than territory, was an essential element of state self-determination projects. ${ }^{106}$ Thus, the question of nationality, which had been practically abandoned to the sphere of private international law, was languishing among scholars, with a decreasing number of pages devoted to it, ${ }^{107}$ between quotations from the obiter dictum, incomprehensibly treated as a hard and fast rule of international law, from the old and outdated Nottebohm case; ${ }^{: 08}$ references to diplomatic protection; ${ }^{109}$ and thoughtful jurisprudential studies on the principle of effectiveness in international law. ${ }^{\text {"о }}$

The vis attractiva of human rights and globalization, however, gave international law on nationality a second chance. ${ }^{\mathrm{II}}$ After the intense movements of people and changes in borders that followed World War II, states came to the conclusion that a world full of stateless persons was too dangerous an option to be allowed. Accordingly, they introduced article 55 into the Universal Declaration of Human Rights (UDHR), which codified nationality as a fundamental right, including change, while prohibiting

${ }^{10} 4$ See, for all, S. Douglas-Scott, “What Happens to 'Acquired Rights' in the Event of a Brexit?", U.K. Constitutional Law Blog (20I6); or Fernández \& López, supra n. Ioo. Waibel, on the other hand, argues that the right of permanent residence would be protected by the doctrine of acquired rights. See Waibel, supra n. Ioo, at 444 .

${ }^{105}$ Classical treatment of this international law of nationality can be found in "Nationality in International Law", 28 Transactions of the Grotius Society (1942) I5I-168; or H. Goldschmidt, "Recent Applications of Domestic Nationality Laws by International Tribunals", 28 Fordham Law Review (1959), 689-736. For a treatment of the question from the always original perspective of the New Haven School, see M. Mcdougal H. Lasswell \& Ch. LungChu, "Nationality and Human Rights: The Protection of the Individual in External Arenas", 83 Yale Law Journal (1974) 900-998 [doi:10.2307/795378]. A good summary of the issue of nationality in international law can be found in C. Dumbrava, "Nationality, Citizenship and Ethno-Cultural Membership. Preferential Admission Policies of EU Countries" (Doctoral thesis on file at the EUI, Florence, 2012).

${ }^{106}$ See P.J. Spiro, “Nottebohm and 'Genuine Link': Anatomy of a Jurisprudential Illusion”, Investment Migration Working Papers, IMC-RP $2019 / \mathrm{I}, \mathrm{I}-32$, at I.

${ }^{107}$ In Spain, for example, classic manuals such as that of Díez de Velasco devoted i3 pages to the personal competence of the State, while in more modern ones, such as that of Andrés Sáenz de Santamaría, they were reduced to 2 .

${ }^{108}$ See supra n. 3o. An exhaustive study of the case and all the criticisms it has received can be seen at Spiro, supra n. ıo6; and K. Hailbronner, "Nationality in Public International Law and European Law”, in R. Bauböck et al.(eds), Acquisition and Loss of Nationality. Policies and Trends in 15 European States (Amsterdam University Press, Amsterdam, 2006) 35-104 [doi:Io.5II7/9789053569207].

${ }^{109}$ See E. Denza, "Nationality and Diplomatic Protection", 65 Netherlands International Law Review (2or8) $463-480$ [doi.org/10.1007/s40802-018-0I19-4].

по See the classical work of A. Miaja, "Nuevas realidades y teorías sobre la efectividad en Derecho Internacional”, III Anuario de derecho internacional (1976) 3-47.

II See P.J. Spiro, “A New International Law of Citizenship”, 105 American Journal of International Law (2013) 694-746, at 694 [doi:Io.5305/amerjintelaw.105.4.0694]. 
arbitrary deprivation of nationality. ${ }^{112}$ Globalization, on the other hand, has led to a renewed interest in nationality and dual nationality issues, which were once demonized and are now even encouraged, ${ }^{113}$ and to profound changes in the very essence and function of citizenship. ${ }^{114}$

It is precisely this vis attractiva that caused many authors to turn to international law on nationality and human rights in their quest to find limits to the loss of citizenship rights because of Brexit. Some argued that since the loss of European citizenship was not necessary for the United Kingdom to leave the $\mathrm{EU}$, it could then be considered arbitrary and therefore prohibited by international law. ${ }^{15}$ Others speculated that, since it was not entirely clear whether the loss of citizenship status as such, not that of any of the associated rights, could be challenged before any judicial body, it could eventually be considered arbitrary. ${ }^{\mathrm{I1}}$

The doctrine of the "genuine link", formulated by the International Court of Justice in the aforementioned Nottebohm case, used by the CJEU in some of its judgments in the form of social integration, and read in conjunction with the right to enter and leave one's own country as laid down in Article 12 of the International Covenant on Civil and Political Rights, has also served to argue for a new perspective on the protection of European citizenship in the event of withdrawal from a Member

"2 The law contained in the UDHR was incorporated into several human rights treaties, including two specific conventions to prevent statelessness, the 1954 Convention relating to the Status of Stateless Persons and the 196 I Convention on the Reduction of Statelessness, which have curiously received a low number of ratifications. The Covenant on Civil and Political Rights, on the other hand, only included the right to nationality of children and the right to leave and enter one's own country but was silent on the question of change of nationality. Within the European framework there is also a Convention on nationality which has been ratified by only twelve EU Member States. An overview of the issue of nationality and human rights can be found in S. Price, “The Right to Renounce Citizenship”, $4_{2}$ Fordham International Law Journal (2019) I547-I582, at I55Iff. Doctrinal attention to the situations that lead to the loss of nationality has also been intense. See J. Lepoutre, "Citizen Loss and Deprivation in the European Union (27+I)", EUI Working Papers, RSCAS 2020/29 (2020) I-36 [doi:/ıo.2139/ssrn.3657076]; R. De Groot, R., "Survey on Rules on Loss of Nationality in International Law Treaties and Case Law", 57 CEPS Paper in Liberty and Security in Europe (2013); R. Bauböck \& V. Paskalev, "Cutting Genuine Links: A Normative Analysis of Citizenship Deprivation”, 30 Georgetown Immigration Law Journal (2016) $47^{-104}$.

"I3 On recent issues relating to nationality and international law, see the special issue of the Netherlands International Law Review of 2018 devoted exclusively to the topic. On the evolution that dual nationality has undergone, see the entertaining story of P.J. Spiro, At Home in Two Countries. The Past and Future of Dual Citizenship (NYU University Press, New York, 20I6).

I/ On the evolution suffered by the institution, see, for example, Ch. Joppke, "The Inevitable Lightening of

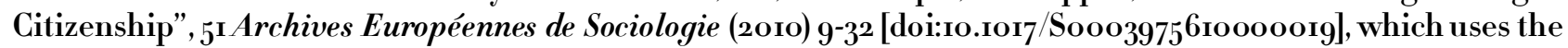
case of EU citizenship to illustrate these changes; or K. Henrard , "The shifting Parameters of Nationality”, $6_{5}$ Netherlands International Law Review (2019) 269-297 [doi.org/I0.1007/s40802-018-0II7-6], which also contains, along with the socio-political transformations that citizenship has undergone, a good summary of the changes that have taken place in international nationality law.

" See Worster, supra n. 3o, at $\mathbf{3}^{62}$.

n6 See Mindus, supra n. I5, at 8o-8I. The author concludes, however, that the only certainty in applying the prohibition of arbitrariness would be in cases of retroactive restrictions. Ibid, at 62 . There he agrees with Kochenov, supra n. 94, at $\mathbf{5}_{5}$. However, Mindus concedes that, applying what has been done in cases of State succession, the only sure principles one can draw from international law are the obligation to negotiate a solution and the obligation to inform the persons concerned. 
State based on the social links that a national of another state has established in another host Member state. ${ }^{117}$

Finally, the case law of the European Court of Human Rights, for example the Kurić case, has also given rise to the possibility of intervention by the Strasbourg Court because of the possible effect of Brexit on the right to respect for private and family life under Article 8 of the European Convention on Human Rights (ECHR). ${ }^{\mathrm{I} 8}$ Or even, bearing in mind that British citizens with dual nationality from another EU country will continue to be European citizens, for violation of the prohibition of discrimination under Article 14 ECHR. ${ }^{\prime 9}$

Legal speculation and prospective work are an essential part of academic life, not to mention the potential income that writing reports and studies can bring to the never sufficiently paid researchers. It is therefore not a matter of questioning the interest or the opportunity to venture into the arcanes of international law in search of a foothold to curb the most undesirable effects of Brexit on the lives of people. Nor do I seek to refute or clarify the content of the sources used for these legal constructs or their application to the case in question. But it is important to point out that many of these legal exercises are based on an unrealistic conception of what international law is, of its relations with politics and of the real limits that, beyond academic formalism, the international legal order imposes on the still sacrosanct state sovereignty. To this end, nothing better than starting with what the EU and the United Kingdom agreed to do in practice with the European citizens affected by Brexit.

\section{(E) THE TRUE LIMITS OF EUROPEAN CITIZENSHIP: WELCOME BACK TO INTERNATIONAL LAW}

On 30 January 2020, the EU and the United Kingdom of Great Britain and Northern Ireland reached an agreement on the withdrawal of the latter from the EU and the European Atomic Energy Community. ${ }^{120}$ The Agreement was accompanied by a Political Declaration on future relations between the European Union and the United Kingdom. ${ }^{\text {I2I }}$

The basic lines of the scheme envisaged for $E U$ and UK citizens derived from both texts are quite simple and based on common sense, self-interest and reciprocity. ${ }^{122}$ Until $3^{\text {I }}$ December 2020 the free movement of EU citizens continues as if nothing had happened. After that date, provision is made for exemption from visas for short visits (up to three months within a six-month period) and business visits, and compliance with the respective migration provisions in force for those wishing to settle in the UK or the EU. For nationals of both sides who were residing on the territory of the other on $3^{\mathrm{I}}$ December 2020, their status is maintained if they met the requirements for permanent residence. 0 therwise, they are given a temporary residence permit until they complete the time required to acquire permanent residence. ${ }^{123}$ Obviously, the Agreement assumes the disappearance of the European citizenship of British nationals at the end of the transitional period.

\footnotetext{
${ }^{\text {п7 }}$ See Strumia, supra n. 87 , at $75^{\mathrm{Iff}}$.

ı8 Mindus, supra n. I5, at 68-69; Strumia \& Hadzimusic, supra n. 99, at I3-I4.

п9 See House of Lords, supra n. 99, at $3^{\text {Iff. }}$

ז20 Published in the OJ $3^{\text {I January 2020, L } 29 .}$

${ }^{22}$ Political declaration setting out the framework for the future relationship between the European Union and the United Kingdom, OJ 3 I January $2020, \mathrm{C}_{34}$.

${ }^{122}$ In fact, this word, or its derivatives, is repeated up to six times in the Political Declaration.

${ }^{2} 3$ See Herbert, Smith, Freehills, Brexit Legal Guide. Migration,
} 
Considering that there are currently around three million EU nationals working in the $\mathrm{UK}$, and over one million British nationals living and working in EU countries, ${ }^{12 /}$ no classic international lawyer would have been surprised by the agreement reached. The sovereign interest of the parties, built on reciprocity of obligations, plus an elementary sense of justice based on the protection of legitimate expectations generated during the UK's membership of the Union left little room, in a law of a contractual nature, for other types of agreements. But they would have raised their eyebrows in awe before the legal theories that proposed maintaining the "acquired rights" of millions of people despite having lost their EU citizenship as a result of the withdrawal of the sta te of which they are nationals from an international treaty. ${ }^{125}$

In view of the doctrinal contributions seen above, this does not seem to be the case for those who are currently approaching international law. Contemporary international law has at least a complex relationship with the notion of state sovereignty —in Bodin's classic words, the absolute and perpetual power of a Republic, ${ }^{\mathrm{I} 2}$ 'organized hypocrisy', for Krasner”-,${ }^{\mathrm{I} 27}$ and its implications.

Indeed, the existence of the sovereign state is a sine qua non of international law since its birth, and even its possibility of being depends on the existence of independent political entities acting with the conviction of being linked on an equal footing. At the same time, state sovereignty is an obstacle to the development of international law as an order capable of dealingwith global problems, and a real threat to its legality. After all, what kind of order would this be if its subjects could dispose of it at will according to their interests?

Many international lawyers have solved this basic dialectic in their discourse -the state is a requirement for the emergence of international law and its survival an obstacle to its advancement- by resorting, on the one hand, to technical-legal formalisms of the type "consensus", "general principles of law", "common material values”, or "ius cogens" which guarantee the total non-availability of the law in the hands of its subjects and, therefore, its normative character. ${ }^{128}$

On the other hand, they have resorted to the notion of progress, perceptible in seminal works such as Friedmann's Changing Structure of International Law, by inscribing that dialectic in an inexorable continuum that goes from the initial sacrosanct sovereignty of states to "internationalism", "globalism" or the "constitutionalisation of the international legal order". Those developments will allow us, in a Kantian cosmopolitan vein, to transcend state borders in the solution of problems that go beyond the artificial territorial barriers. As Martti Koskenniemi, the so-called "rock star" of international law, rightly summed up, international lawyers have used sovereignty to limit sovereignty itself. ${ }^{229}$

${ }^{2} 4$ See UK(Office for National Statistics), Population by Country of Birth and Nationality Report: August 20 I $_{5}$.

${ }^{25}$ See J. Herbst, "Observations on the Right to Withdrawal from the EU: Who are the "Masters of the Treaties'?”, 6 German Law Journal (2005) I755-176o [doi:ıo.ıог7/S207183220001467X].

${ }^{126}$ J. Bodin, Los seis libros de la república (Tecnos, Madrid, 1997), at 47-48. The original work is from ${ }_{57} 6$.

${ }_{127}$ S.D. Krasner, Sovereignty: Organized Hypocrisy (Princeton University Press, Princeton, I999).

${ }_{12} 8$ See I. Forcada, "El concepto de Derecho Internacional Público en el umbral del siglo XXI: la "Nueva Corriente”, IX Anuario Argentino de Derecho Internacional (I999) I8I-22o; and "La enseñanza del Derecho Internacional Público en España: una perspectiva desde el análisis crítico del discurso”, 3 REEI I-28.

ז29 See M. Koskenniemi, "What Use for Sovereignty Today?”, I Asian Journal ofInternationalLaw (2011) 6I-70, at 62 [doi:ıo.ror7/S204425I3IOoooo44]. We owe the name rock star to Janne E. Nijman, Academic Director of the T.M.C. Asser Institute, in the preface to the Fourth Annual T.M.C. Asser Lecture taught by Koskenniemi in 2018 and available at M. Koskenniemi, International Law and the Far Right: Reflections on Law and Cynicism (T.M.C. Asser Press, The Hague, 2or9), at v. 
From there to think that, faced with a sovereign decision to withdraw from a treaty, and thus erase with the stroke of a pen the citizenship rights of more than sixty million people, one could, like Moses and the Tables of the law, turn to the international legal order, including its courts, and find limits with which to curb state sovereignty, i.e., political decisions, was a small step that many, according to the literature studied in these pages, have not hesitated to take.

At the very least, a waste of time. At best, a serious conceptual error that affects, on the one hand, what European citizenship means; on the other, the role of sovereignty in a law of a contractual nature such as international law. An error which explains the concern of some, in the style of what happened with the debate on fragmentation, with the wave of populism that sweeps through international relations, and the renewed academic interest in finding limits to the withdrawal from multilateral treaties. ${ }^{1{ }^{\circ}}$ Let us take it one step at a time and start with the misperception of European citizenship.

It is obvious that the creation of a European citizenship had no intention of usurping any essential competence of the Member States. ${ }^{1{ }^{31}}$ In fact, the EU had borrowed a concept with a heavy political and legal legacy, citizenship, and incorporated it into its conceptual system by stripping it of its traditional content and meanings. ${ }^{{ }^{2}}$ What really interested the $\mathrm{EU}$ in a concept such as citizenship was the symbolism contained in it. The European Commission itself recognized this when it declared, with that style of political communication typical of the $\mathrm{EU}$, in which the institution itself becomes a product to be "placed" within a strategy of "brand development", ${ }^{133}$ that European citizenship was intended to promote the idea of a European identity which, in turn, would guarantee citizens' support for the integration project. ${ }^{134}$

The implicit assumption therefore in the invention of European citizenship is that it would serve to reaffirm European identity. The greater the European identity, the greater the support for the

r3o On the advance of populism and its repercussions on the international liberal law that we had been experiencing, see J. Crawford, “The Current Political Discourse Concerning International Law”, 8I The Modern Law Review (2018) I-22 [doi:Io.III/I468-2230.I23I/]; and M. Koskenniemi, Far Right..., supra n. I33, at Iff., and the literature that is cited in both. For an example of this renewed interest in withdrawal from multilateral treaties, see H. Woolaver, "From Joining to Leaving: Domestic Law's Role in the International Legal Validity of Treaty Withdrawal”, 3 o European Journal of International Law (2019) 74-104 [doi:Io.2139/ssrn.3352437].

I3 Its derivative character, first, and complementary, later, are there to testify.

${ }^{132}$ As we have seen, European citizenship was derived from state nationality, and was basically a mere systematization of rights, which already existed under the Treaties, and secondary law. See C. Closa, "The Concept of Citizenship in the Treaty on European Union”, 29 Common Market Law Review (I992) II37-II69.

${ }^{1} 3$ See J.H.H. Weiler, The Constitution of Europe: Do the New Clothes Have An Emperor?' and Other Essays on European Integration (Cambridge University Press, Cambridge, I999) cited in T. Tsaliki, "The Construction of European Identity and Citizenship Through Cultural Policy”, 24 European Studies (2007) I57-I82, at I66 [doi:ıo.ıI63/97894ог204I56_oго].

I34 “Citizenship of the Union conferred on all nationals of all Member States by the Maastricht treaty is meant to make the process of European integration more relevant to individual citizens by increasing their participation, strengthening the protection of their rights and promoting the idea of a European identity”. EC Commission, Second Report from the Commission on the Citizenship of the Union, Doc. COM (97) 230 final (I997), at I. In the third report, the Commission recognized that citizenship was "both a source of legitimation of the process of European integration, by reinforcing the participation of citizens, and a fundamental factor in the creation among citizens of a sense of belonging to the European Union and of having a genuine European identity”. EC Commission, Third Report from the Commission on the Citizenship of the Union, Doc. COM (200I) 506 final (200I), cited in M. Vink, , “The Unbearable Lightness of European Citizenship”, 6 Citizenship, Social and Economics Education (2004) 24-33, at 25 . 
integration project. From this point of view, citizenship became a useful propaganda tool not only to secure the consent of "Europeans", but also to create, in the first place, the very category of Europeans. ${ }^{135}$

But, as we have seen, European citizenship was stripped of the traditional content of the institution, reduced to its symbolic potential, and used as a marketing instrument to sell on the market, as true citizenship, what was only a reinforced variant of free movement of persons provided for in the Treaties. Something radically insufficient to make it the engine of the citizen's approach to institutions desperately in need of popular legitimation. This is why the polls continue to show us, for more than $3^{\circ}$ years, that national sentiment continues to be the master identity of Europeans. ${ }^{1{ }^{6}}$

The title of the issue No. 3 o of the journal Politique européenne, "L'identité européenne, entre science politique et science fiction", is therefore a good summary of the state of play of the citizenship/identity binomial in the EU. The obsession of institutions, doctrine and surveys with the identity question, with people's opinions, feelings or beliefs about the EU, has made them lose sight of the fact that what is really interesting is what people did or could do in an integrating Europe. ${ }^{137}$ Not their feelings, but their actions.

However, relying on the CJEU jurisprudence, the most pro-European academic doctrine, always more concerned with debating the normative potential of institutions than with its actual use, has projected onto European citizenship its great cosmopolitan illusions of a post-national state based on a demos that the citizenship itself would contribute to give birth. And it has devoted, consequently, its disciplinary effort to discover the conditions in which a "true" European citizenship would be possible.

Deep down, a waste of time. The jurisprudence of the CJEU, which was exceptional and interpreted restrictively afterwards, did not really say what they thought. And what is worse, all that potential that the doctrine spoke of, that "milestone" in the integration process, only really affected a little more than two percent of the population. ${ }^{1{ }^{8}}$ As one author put it, "the great promise of UE citizenship had only ever really taken hold in the ivory towers of academic imagination and the European Court of Justice”. ${ }^{39}$

But the problem does not end up there. If European citizenship was to promote European identity, and thus ensure greater public support for the integration project, then we can only speak of a resounding failure. The percentages of support for the integration project have not changed significantly in the last 30 years because they respond to other conditioning factors. What is more serious, empirical studies show that these European citizens who have chosen to settle in another country of the Union and who, as such, make full use of the new possibilities offered by integration, are

${ }_{35}$ See Shore, supra n. 34, at $3^{\mathbf{I}}$.

${ }^{136}$ The graphs with the temporal evolution and the divergences between countries can be seen in S. Ciaglia, C. Fuest. \& F. Heinemann, “What a feeling?! How to promote 'European Identity”, , EconPol Policy Report (2018) I- $6_{5}$, at I6-I7. This work also contains an interesting breakdown of the different determinants that influence the shaping of European identity, such as education, social class, economic resources, personal characteristics.

${ }^{137}$ SeeA. Favell, “European Identityand European Citizenship in Three 'Eurocities': ASociological Approach to the European Union”, 3o Politique Européenne (2010), 187-224, at 197 [doi:1o.3917/poeu.o30.0187].

${ }^{13} 8$ See M. Benton \& M. Petrovic, How free is free movement? Dynamics and drivers of mobility within the European Union (Migration Policy Institute Europe, Brussels, 2013), at 3. This explains why 6o percent of Eurobarometer respondents do not know what their rights are as EU citizens. Also explains why the supposedly informed friends whom I asked out of curiosity, while writing this article, about European citizenship, all looked at me as if $I$ had asked them about the fusion of weak vector bosons.

I39 O’Brien, supra n. 66, at 974 
far from showing more interest and attachment to the construction of a political community on a European scale than the other Europeans. ${ }^{14^{\circ}}$

In reality, the conceptual error that explains both the academic drift in search of a non-existent Holy Grail, and the incongruous institutional effort to use part of the legal repertoire of the nation state to increase popular adherence to a post-national project, has to do with the widespread belief in a democratic deficit, and the subsequent search for legitimacy to reduce it. ${ }^{1 / t^{1}}$

Instead of looking at the actual use of mobility rights, in which the fundamental freedoms provided for in the Treaty are translated, considering this mere use alone as legitimizing the European project, the EU institutions and the Europeanist doctrine that supports them, fundamentally incapable of moving away from the paradigm of the nation state, embarked into the search/creation of a European people on which to democratically support the entire integration project. With that idea in mind, the creation of a European citizenship was obviously a good choice whose only defect could only be the timidity of the content with which it was designed.

Nothing could be further from the truth. It is the historical and social factors, woven into the fabric of people's daily lives, that give substance and legitimacy to a political community. Not the social engineering exercises based on political marketing. Instead of opting to favor mobility policies which, through small gradual changes, end up generating these historical and social factors, they wanted to start by putting the cart before the horse, deceiving us with the claim that, overnight, we had all become European citizens.

Hence the confusion with which this doctrine we have analysed welcomed the British decision of Brexit. The dreams of a European demos, of the overcoming of the nation-state and its sovereign freedom, of a post- or trans-national European citizenship that would do away with national ethnocentric particularisms, were dashed by a democratic decision of a markedly nationalistic nature, based on eternal national sovereignty, which erased with the stroke of a pen the obviously unacquired mobility rights of more than 60 million supposed European citizens.

From there also the desperate recourse to international law which, thanks to its recent drift towards human rights, and its connection with concepts such as ius cogens and erga omnes obligations, which make it possible to assert the unavailability of the law on the part of its subjects, has seen its juridical basis grounded in something more solid than the changing will of the state. The problem is that the international law that they sought to use as a limit to the exercise of national sovereignty existed only in their imagination, and not only because sovereignty has obviously not disappeared. ${ }^{1 / 2}$ These errors are the result of a paradigmatic reductionism, a set of historically contingent and aprioristic ideas that controlled their disciplinary thinking

The first paradigmatic error they made fully affects treaties as a source of rights and obligations. Fleeing from accusations of irrelevance and non-legal character, ${ }^{143}$ and relying weakly on what appears

${ }^{140}$ See Favell, supra n.I37.

${ }^{14}$ ' SeeA. Moravcsik, "In Defense of the "Democratic Deficit”: Reassessing Legitimacy in the European Union", Center for European Studies Working Paper No. 92 (2003) who maintains that concern about the democratic deficit in the EU is misplaced.. Cf. A. Follesdal \& S. Hix, "Why there is a democratic deficit in the EU: A Response to Majone y Moravesik", Journal of Common Market Studies (2006) 533-562 [doi:Io.III/j.1468-5965.2006.oo650.x].

1/2 See S. Krasner, “Think Again: Sovereignty“, Foreign Policy, 20 November 2009.

${ }^{143}$ See C. Douzinas, Human Rights and Empire. The political philosophy of cosmopolitanism (RoutledgeCavendish, Abingdon/New York, 2007). Professor Douzinas does not seem to hold international lawyers in high 
to be a de facto concordance between norms and state behaviour to demonstrate the relevance and legal character of the former, many authors devoted their disciplinary energy to demonstrating a normativity of treaties that went so far as to bind states regardless of their interests or opinions. Forgetting along the way that, as the classics already warned, ${ }^{1 / 4}$ it is economic calculation based on rational decisions, and the interest and power of states, including the long-term interest of obeying a rule that goes against their apparent short-term interest, that explain state adherence to regimes or treaties, and also their withdrawal. ${ }^{145}$ Something that led John R. Bolton, who was Assistant Secretary of State for International Organization Affairs, Permanent Representative of the United States to the United Nations, and National Security Adviser with Donald Trump, to affirm before the Relations Committee Internationals of the US Congress, without dropping his rings, that "in their international operation, treaties are simply 'political,' and not legally binding". ${ }^{1{ }^{6} 6}$

The second error concerns the role, function, and limits of international jurisdictions in the functioning of the international legal order. Based on some jurisprudential decisions that seemed to limit sovereign options, such as the aforementioned Nottebohm case, or the expansive jurisprudence of the GJEU in matters of European citizenship, they wanted to seek insurmountable limits to state sovereignty there as well. Forgetting once again that international courts, much more than other high courts of the internal order, are exceptionally sensitive to questions of legitimacy that can damage their survival. It is simply then inconceivable that they could adopt decisions that would counteract other sovereign decisions of a democratic nature that affect millions of people, as it is proven by the irrelevance in the real world of the Nottebohm doctrine, or the turnaround in the Court's case law on matters of European citizenship. ${ }^{147}$

regard: "Academically, international law is seen as a peripheral exercise, closer to the doubtful pursuits of international relations rather than to a fully formed legal discipline"; "One is tempted to say that there is something seriously flawed with this branch of law"; "Its palindromic nature makes it more elastic than a rubber band"; "one concludes that people are not wrong to remain in their blissful ignorance and indifference towards this branch of law"; "International law practice is closer to the Protestant tradition under which individuals interpret the holy texts freely rather than to the Catholic authoritative renditions by the Church"; "The international lawyer is the lawyers' lawyer, someone who spends a lifetime pouring over the text of treaties, their traveaux préparatoires and the few 'soft' decisions of international tribunals"; "The international lawyer's professional identity is in direct conflict with her practical effectiveness. As a result, international lawyers live in a permanent existential crisis. Their hazar professionel is that they are the ultimate exponents of a law whose power is in reverse proportion to its certainty...Their endless musings about the status of their discipline is quite unique in the legal academy...Conferences often seem to become exercises in group therapy"; "International law with all its contradictions and paradoxes is leading us into empire", at I98, $2 \mathrm{I}_{5}, 233,234$.

${ }^{144}$ See M. Koskenniemi, “The Advantage of Treaties: International Law in the Enlightenment”, I3 Edinburgh Law Review (2009) 27-67 [doi.org/10.3366/E13649809o80oo954].

${ }^{1} 45$ See J.L. Goldsmith \& E.A. Posner, The Limits of International Law (Oxford University Press, Oxford, 2005) at 83 ff.

${ }_{146} 6$ See K.L. Kirgis, “Treaties as Binding International Obligation“, 2 ASIL Insights (1997), at I.

${ }_{147}$ On the irrelevance of the Nottebohm doctrine in subsequent practice, see Spiro, supra n. Io6. On the explanation of the change in the jurisprudence of the GJEU, see M. Blauberger et al., "ECJ Judges read the morning papers. Explaining the turnaround of European citizenship jurisprudence", 25 Journal of European Public Policy (2018) I/422-I/4I [doi.org/I0.1080/13501763.2018.I/48880]. The sensitivity of the CJEU to the political views of the Member States does not detract from the fact that its decisions have a high impact on their policies. See M. Blauberger \& S.K. Schmidt, "The European Court of Justice and its political impact”, 4o West European Politics (2017) 907-918 [doi:10.1080/o1402382.2017.1281652]. 
The third error consists in forgetting that international law, as a cultural expression of the species, enjoys a strictly epiphenomenal nature, that is, secondary and derived from another main or determining phenomenon. In other words, an accessory phenomenon that accompanies the main phenomenon, the sovereignly expressed will of the state, and which does not have much influence on it. This oblivion is what has allowed many to approach international law through a technical-legal analysis typical of the discipline, accepting without further ado the marginal task of deciding the bureaucratic details of political negotiations. ${ }^{14^{8}}$ As Morgenthau correctly summarized, trying to exorcise social ills through the tireless repetition of magic formulas. ${ }^{1} 49$

Ultimately, these errors are written on a background image of the fragility of international law and serve to encourage those who turn to it to focus on technical problems like compliance, enforcement, or on criminal, procedural or administrative law. Thus, directing attention to the development of mechanisms, strategies, or institutional initiatives to overcome what is thought to be an innate predisposition on the part of governments to ignore international commitments when they appear to be inconvenient. As Douzinas noted, "normative jurisprudence has acquired its own unreality because of its total neglect of the role of law in sustaining relations of power and its descent into uninteresting exegesis and apologia for legal technique". ${ }^{150}$

A paper world incapable of reflecting the world in which the rest of the people live,${ }^{15 \mathrm{I}}$ i.e. a "world where nations, individually or in groups, decide for themselves, guided by their own morality and sense of justice and order". ${ }^{152}$ For Kagan, this is the world we live in, and the only world we have ever lived in. A world where those in power, believing that the law is on their side, impose their sense of justice on others. ${ }^{153}$ The world of international law.

I am aware that these words may seem somewhat cynical, and that cynicism, even in international law, does not get a good press. ${ }^{154}$ Although I consciously practice kuviкó $\varsigma$ (cynicism), in its philosophical meaning, i.e. anaideia, adiaphoria and parresia, ${ }^{1,55} \mathrm{I}$ do care quite a lot about the world I live in. That is why I do not want to close this writing without resorting to an argument of authority that would strip it of any irreverent stain.

${ }_{14}^{18}$ See O. Korhonen, "New International Law: Silence, Defence or Deliverance”, 7 European Journal of International Law (1996) I-28, at II [doi:ı.ı.1093/oxfordjournals.ejil.aor5485].

${ }_{149}$ Phrase that Morghentau applied to the formalists of the inter-war period. See H. Morghentau, "Positivism, Functionalism and International law", 34 American Journal of International Law (1940) 260-284, at 26o [doi:10.2307/2192998].

${ }^{150}$ C. Douzinas, The End of Human Rights (Hart, Oxford, 200o), at 7, cited in D. Kritsiotis, "When states use armed force", in C.H. Reus-Smit, (ed), The Politics of International Law (Cambridge University Press, Cambridge,

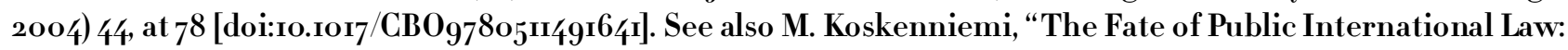
Between Technique and Politics", 7o The Modern Law Review (2007) I-30 [doi.org/I0.IIII/j.I468$2230.2006 .00624 x]$.

${ }^{\mathrm{r} 5^{5}}$ See M. Walzer, Just and Unjust Wars: A Moral Argument with Historical Illustrations ${ }^{{ }^{\mathrm{rd}}}{ }^{\mathrm{d}}$ ed., Basic Books, New York, 200o), at xix.

${ }^{152}$ See R. Kagan, Paradise and Power (Atlantic Books, London, 2004) at ${ }_{130 .}$

${ }_{53}$ Ibid., at I3I.

${ }^{5} 5$ See Koskenniemi, Far Right..., supra n. 129.

${ }^{55}$ Irreverence or provocation; indifference; and frankness or freedom of speech. On parresia it is always illustrative to take a look at what Foucault said about it in the series of lectures he gave at the University of Berkeley (California) in 1983 . 
If anyone wants to know, by reading just one of the articles quoted here, the legal intricacies and political possibilities triggered by Brexit, I recommend reading the article written by Jean-Claude Piris, even before the Brexit referendum, on the legal aspects of the UK's withdrawal and the effects of the different options being considered..$^{15}$

Piris is one of those excellent jurists who, like Claus-Dieter Ehlermann, have directed the legal services of the European institutions. It is likely that, despite their impeccable academic training, their passage through the real world has made them temper the tendencies towards legal musings that are so abundant in the academic world, thus acquiring an extraordinary power of synthesis to address what, in International life, are always complex legal-political problems.

In the case of Brexit, after describing the content of Article $5^{\circ}$ TEU and the possible options that were opening up (all not too good for the UK), Piris addressed, and dispatched, in a few highly predictive lines, the problem of European citizenship:

"Personally, I would not think that one could build a new legal theory, according to which "acquired rights" would remain valid for millions of individuals (what about their children and their grand children?), who, despite having lost their EU citizenship, would nevertheless keep its advantages for ever... It is mostly probable that solutions, at least ad interim, would be found rapidly. Any agreement would be based on classic international law and in particular on the principle of reciprocity. This means that all rights obtained in favor of British citizens in EU Member States (which will not be able to negotiate individually with the $\mathbf{U K}$, as they are all bound together by $\mathbf{E U}$ law on these issues) will have to be granted to nationals of all twenty eight EU Member States". ${ }^{57}$

Quite right, isn't it?

${ }^{15} 6$ See J.C. Piris, “Should the UK Withdraw from the EU: Legal Aspects and Effects of Possible Options”, Robert Schuman Foundation/European Issues, Policy Paper n. 355 (2015) I-I3.

I57 Ibid. at Io. 